NBER WORKING PAPER SERIES

\title{
THE TRILEMMA IN HISTORY: TRADEOFFS AMONG EXCHANGE RATES, MONETARY POLICIES, AND CAPITAL MOBILITY
}

\author{
Maurice Obstfeld \\ Jay C. Shambaugh \\ Alan M. Taylor \\ Working Paper 10396 \\ http://www.nber.org/papers/w10396 \\ NATIONAL BUREAU OF ECONOMIC RESEARCH \\ 1050 Massachusetts Avenue \\ Cambridge, MA 02138 \\ March 2004
}

This paper was originally prepared for the conference "The Political Economy of Globalization: Can the Past Inform the Present" sponsored by the IIS at Trinity College, Dublin and funded in part by the European Science Foundation. The authors thank the attendees for comments and the sponsors for financial support. We also thank participants at the NBER's Fall 2002 program meeting in international finance and macroeconomics and the Fourth Annual IMF Research Conference, particularly our discussants, Jeffrey Frankel, Lars Svensson, and Helene Rey. Obstfeld gratefully acknowledges the financial support of the NSF, through a grant to the NBER. Taylor gratefully acknowledges the support of the Chancellor's Fellowship at the University of California, Davis. We thank Julian di Giovanni and Miguel Angel Fuentes for excellent research assistance. The views expressed herein are those of the author and not necessarily those of the National Bureau of Economic Research.

(C2004 by Maurice Obstfeld, Jay C. Shambaugh, and Alan M. Taylor. All rights reserved. Short sections of text, not to exceed two paragraphs, may be quoted without explicit permission provided that full credit, including $(\mathrm{C}$ notice, is given to the source. 
The Trilemma in History:

Tradeoffs among Exchange Rates, Monetary Policies, and Capital Mobility

Maurice Obstfeld, Jay C. Shambaugh, and Alan M. Taylor

NBER Working Paper No. 10396

March 2004

JEL No. F33, F41, F42

\title{
ABSTRACT
}

The exchange-rate regime is often seen as constrained by the monetary policy trilemma, which imposes a stark tradeoff among exchange stability, monetary independence, and capital market openness. Yet the trilemma has not gone without challenge. Some (e.g., Calvo and Reinhart 2001, 2002) argue that under the modern float there could be limited monetary autonomy. Others (e.g., Bordo and Flandreau 2003), that even under the classical gold standard domestic monetary autonomy was considerable. This paper studies the coherence of international interest rates over more than 130 years. The constraints implied by the trilemma are largely borne out by history.

\author{
Maurice Obstfeld \\ Department of Economics \\ 549 Evans Hall \#3880 \\ University of California \\ Berkeley, CA 94720-3880 \\ and NBER \\ obstfeld@econ.berkeley.edu \\ Jay C. Shambaugh \\ Department of Economics \\ 309 Rockefeller Hall \\ Dartmouth College \\ Hanover, NH 03755 \\ Alan M. Taylor \\ Department of Economics \\ University of California \\ One Shields Avenue \\ Davis, CA 95616-8578 \\ and NBER \\ amtaylor@ucdavis.edu
}

jay.c.shambaugh@dartmouth.edu 
The characterization of economic globalization as a "golden straitjacket" evokes two distinct sets of questions. ${ }^{1}$ One can ask how golden the jacket is, or else how strait it is. The former question has occupied many applied economists, who have studied the relationship of openness to growth and so forth. The latter question has been much less studied, yet it appears equally important for any overall assessment of the costs and benefits of economic openness. The goal of this paper is to examine the constraints that financial globalization places on macroeconomic policies.

At the most general level, policymakers in open economies face a macroeconomic trilemma. Typically they are confronted with three typically desirable, yet contradictory, objectives:

1. to stabilize the exchange rate;

2. to enjoy free international capital mobility,;

3. to engage in a monetary policy oriented toward domestic goals.

Because only two out of the three objectives can be mutually consistent, policymakers must decide which one to give up. This is the trilemma. If monetary policy activism (3) is taken to mean the ability to drive local interest rates away from the world rate-the criterion we shall employ here - then arbitrage in open capital markets (2) and simple interest parity under a credibly fixed exchange rate (1) clearly defeat the objective. Despite the clarity and simplicity of this prediction, one is surprised by the frequency with which the lessons of the trilemma seem to be disregarded by policymakers, even today. This might reflect the lack of empirical studies showing how tight the constraints of the trilemma really are.

Major empirical challenges confront anyone seeking empirical measures of the three economic objectives underlying the trilemma. The first element, the exchange rate, is perhaps the simplest to measure. One might use the volatility of the exchange rate, or a simple binary indicator of pegging or not pegging. However, even here some disputes arise. Should one employ unconditional or conditional volatility measures? If using an indicator variable, should the exchange rate regime be classified by its de jure or de facto status? A country's actual exchange rate regime choice often departs from its self-reported status, as published by the International Monetary Fund (IMF). The preferred approach is therefore to examine what countries do, not what they say (Obstfeld and Rogoff 1995; Calvo and Reinhart 2001, 2002; Levy-Yeyati and Sturzenegger 2002; Reinhart and Rogoff 2004).

\footnotetext{
${ }^{1}$ The quotation is from Friedman (1999).
} 
The second element of the trilemma, capital mobility, is even harder to measure. Postwar empirical analysis has tended to rely on the IMF's classifications of capital mobility restrictions, which only have broad coverage in recent decades. These are general qualitative indices and, as with the de jure exchange rate reports, questions have been raised about their de facto accuracy. For an historical study like ours, we face the further obstacle that there exist no comparable sources on pre-1945 capital controls.

The third element, measuring the activism of monetary policy, is also problematic. The approach taken by Rose (1996), for example, uses a simple monetary model of exchange in which the exchange rate responds to "fundamentals" such as money, output, and interest rates. Rose tests how well the model fits the data (in the second moments) to see how exchange rate flexibility is related to "monetary divergence" in two countries, as well as to various controls based on capital mobility indices. His results were "somewhat favorable but surprisingly weak" (p. 926). Still, as many papers have pointed out, we are poorly equipped to identify monetary policy shocks. Using monetary aggregates is unattractive when one cannot easily distinguish between demand and supply shocks to money, and also when the stability of velocity has to be assumed. An older and distinct approach, based on trying to measure the capital-account offset to domestic credit expansion, suffers from similar problems in empirically identifying exogenous credit shocks.

Here we take a different approach. First, our measure of monetary independence will be based not on quantity aggregates, but on observed short-term nominal market interest rates. This approach has intuitive appeal because monetary policy (a few experiments aside) has almost always taken the form of interest-rate targeting or manipulation, with little meaningful reference to money-supply quantity targets. Even if the interest rate is not the primary instrument of monetary policy, it should be directly affected by monetary-policy changes and thus would still serve as a measure of the stance of policy. ${ }^{2}$ If the interest rate is insulated from market

\footnotetext{
${ }^{2}$ Goodhart (1989) notes that "monetary policy operations of the Central Banks" can be viewed as "quantity, or rate setting actions (though, of course, one is the dual of the other)." Generally, central banks have long viewed a shortterm interest rate as their preferred policy instrument. Occasionally a central bank (such as the German Bundesbank starting in the 1970s) has focused on monetary aggregates, a practice that still survives in the European Central Bank's much-debated (but basically irrelevant) "second pillar" of monetary policy. In the process of disinflation beginning in the late 1970s, other central banks, such as the Federal Reserve and the Bank of England, briefly paid attention to quantity targets. In recent decades, financial innovation and instability in money demand has led to a widespread acceptance that quantity targets are impracticable. As Goodhart puts it, "it became generally accepted that adjustments to the general level of short-term interest rates formed just about the only effective monetary instrument."
} 
conditions by capital controls, this is of interest as well in that it demonstrates how capital controls can allow monetary autonomy and a fixed exchange rate to exist simultaneously. That is, it demonstrates the power of the third leg of the trilemma. The question we pose is whether the exchange-rate and capital-control regimes influence the extent to which local interest rates diverge from the "world" interest rate (in some well-defined base-country market). ${ }^{3}$

We focus on the nominal, not real, interest rate for two reasons. The first is that the nominal rate generally is the instrument of the central bank. In addition, though, under free international capital mobility, credibly fixed exchange rates imply that the nominal interest rate in the local country must equal that in the center or base country. On the other hand, international real rates of interest need not be equalized under these conditions. For example, expected changes in real exchange rates can generate international real interest differences even when there is no monetary policy autonomy. As a result, there is no strong theoretical prediction that pegs and nonpegs will look different with regards to real interest rate movements against a base country.

Our approach vastly expands the sample range of experience studied. In particular, our study of international interest rate transmission will encompass historical episodes as far back as $1870 .{ }^{4}$ An enlargement of the data universe is attractive on a number of grounds. First, we can see whether the trilemma has endured over a long period as a useful characterization of policy choice. The more durable it can be shown to have been over the long course of history, the more seriously should its constraints be taken by policymakers. Second, the larger historical adds useful additional variance to the data and reveals useful benchmarks for exactly how tightly the straitjacket of globalization fits in different times and places. Across the different historical eras, very different attitudes toward policy activism and toward capital controls prevailed. Thus, crossera as well as within-era comparisons are important in reaching our conclusions.

Finally, our findings can be compared with historical narratives (e.g., Eichengreen 1996; Obstfeld and Taylor 2004). The classical gold standard was a highly globalized period of mostly

\footnotetext{
${ }^{3}$ As noted below, our approach follows that of Shambaugh (2004) and is closely related to the work of Frankel (1999) and Frankel et al. (2000, 2002). A delicate question arises, of course, over whether an observed nondivergence of such interest rates can be seen as evidence of a tight market exchange-rate constraint, rather than a deliberate policy choice to follow the base country's interest rates for other reasons. We consider this question below.

${ }^{4}$ Specifically, we will try to assess the potency of the trilemma as an overarching explanation of policy constraints in both the pre-World War One gold standard period (1870-1913), the convertible Bretton Woods period (1959-73), and in the post-Bretton Woods era (1974-present). In comparison, Rose (1996) studied the period 1967-92, and
} 
fixed rates, unfettered capital mobility, and, hence, limited monetary independence. The architecture of the post-World War Two Bretton Woods system provided monetary autonomy with relatively stable fixed-but-adjustable exchange rates, necessitating strict limits on capital mobility. These eras offer a clean contrast with the recent era, when countries to greater or lesser degree have dismantled their postwar systems of capital controls. Today, some countries have adopted flexible exchange rates as a route to monetary independence, some have fixed and tied their hands, while others have endured crises and confusion in vacillating between these two "corner solutions."

Are such narratives supported by the data? We think so. In this study we find pronounced and rapid transmission of interest-rate shocks during fixed-rate episodes under the classical gold standard period. In marked contrast, during the Bretton Woods era fixed exchange rates did not provide much of a constraint on domestic interest rates, a clear by-product of widespread capital controls. Now, in the contemporary post-Bretton Woods era, there are signs of reversion to the more globalized pattern, with increased interest rate transmission among fixed-rate countries. Still, an alternative solution of the trilemma is also clearly present in our contemporary findings: nonpegs, both before 1914 and in the present, have enjoyed considerably more monetary independence than pegs. This relative difference in independence provides another important benchmark in showing how to judge the lack of independence under a peg. Overall, as witnessed in the systematic variation in policymakers' room for maneuver, we find strong evidence in support of the trilemma, which emerges in the data as a long enduring and still very relevant constraint on the political policy equilibrium.

\section{Data}

\section{Data Sources}

Our core data are all monthly.

Short-term interest rate data for the gold standard era reflect the arduous collection efforts of Neal and Weidenmier (2003), whom we thank for sharing the resource they have assembled. The Neal-Weidenmier data are available for 15 countries plus the United Kingdom. Before World War One, the UK interest rate is used as the central or base rate with which other

Shambaugh (2004) and Frankel et al. (2000, 2002), the modern post-1970 period through the end of the twentieth century. 
countries' rates are compared. The gold standard interest-rate series start in 1870 for many countries and later for others. All series end in 1914.

Interest rates data for the Bretton Woods era consist of both short-term money market rates (interbank and call money rates) and short term treasury bill rates (generally three-month rates), all average monthly values taken from the IFS CD-ROM and Global Financial Data. ${ }^{5}$ Availability determines which data we use. While the maturity on different types of rate differ slightly, rates for the same country, when available, are in practice extremely highly correlated. Data for 21 countries in addition to the United States are available. The base interest rate under Bretton Woods is the US interest rate (money market or treasury bill) that matches the interest rate used for each local country. Due to a lack of monthly data before 1957, and the expansion of convertibility that took place in 1959, the Bretton Woods data that we examine are limited to the years 1959-70. We stop in 1970 due to the increasing speculation on exchange parity changes that characterized the early 1970 s.

For the post-Bretton Woods era (1973-2000), the interest rates are once again average monthly values of short-term money market and short-term treasury bill rates from the IFS CDROM. Those data are augmented on the basis of Datastream and Global Financial Data. In all, data for 103 countries are available. Given diverse pegging patterns in the modern period, we allow base to differ across countries, as described in Shambaugh (2004). For many countries the United States is the natural base, but the base is Germany for much of Europe, the base is France for some of Africa, and the base is the UK, South Africa, Australia, or India for others. For pegs, the interest rate is obviously the country to which the local country pegs. For pegged countries that are not pegged, the base country is the one to which the local country would most likely follow if it were pegging. This choice is determined by previous pegging history, which is relevant in almost all cases, but otherwise by the dominant currency in the region (the one to which neighboring countries peg). Information from the IMF's Annual Report on Exchange Arrangements and Exchange Restrictions and from B. Taylor (2000) is used as well. Because almost all countries peg at some point in the sample, and those that switch bases usually switch from one peg to another, the assignment of a base currency is generally quite simple. Once again, the base interest rate used is always of the same type (money market or treasury bill) as the one available for the local country.

\footnotetext{
${ }^{5}$ Data for the US are extended back in time using information from FRED on the St. Louis Federal Reserve website.
} 
All interest rates are expressed in the form $\ln (1+R)$. While this has a trivial effect at low to moderate interest rates, it does reduce the impact of outliers. In addition, hyperinflations are excluded from the post-Bretton Woods sample due to the excessive weight they would carry in the regression results.

\section{Exchange-Rate Regime Coding}

Exchange-rate regimes under the gold standard can be determined in two alternative ways: based on the legal commitment of countries to gold (the de jure status) or on the observed behavior of the exchange rate (the de facto status). De jure Gold Standard coding is based on Meissner (2001), Eichengreen (1996), Global Financial Data, and Hawtrey (1947). ${ }^{6}$ De facto classification follows the coding methodology for the post-Bretton Woods era developed in Shambaugh (2004). In applying it under the gold standard, we check whether the end-of-month month exchange rate against the pound sterling stays within $\pm 2 \%$ bands over the course of a year. In addition, single realignments are not considered breaks in the regime as long as the transition is immediate from one peg to another. Finally, single-year pegs are dropped as they quite possibly reflect simply an absence of volatility. In such cases, it seems unlikely that there exists either commitment on the government's part or confidence in the market that the rate will not change. The de jure and de facto criteria are in broad agreement, although many countries begin to peg de facto a number of years before they officially adopt the gold standard. We apply the same de facto test (with respect to the appropriate base currency) to the two other epochs.

For our segment of the Bretton Woods period (1959-70), all countries are pegged both de jure and de facto with the exception of Canada in 1960-61 and 1970, Brazil in the early and late 1960's, the UK in 1967, and Germany beginning in 1969. This lack of diversity is not a result of our sample, but the era. Looking at all 145 countries with exchange rate data from 1960-66, 2.5 per year, on average, are not pegged. In 1967 and 1969, there are some realignments, but all quickly return to pegging. Thus, we will not use the Bretton Woods era to provide a within-era contrast in regimes. Instead, data from the Bretton Woods years yield estimates for an era in which pegs coexisted with capital controls, in contrast to the pegs without capital controls characterizing the gold standard.

\footnotetext{
${ }^{6}$ Bimetallic regimes are treated as pegs. We recognize that this convention is somewhat arbitrary, but it affects only a small number of observations.

${ }^{7}$ When pursuing differences regressions, we also drop the first year of a peg to ensure we are not differencing the interest rate data across nonpegged and pegged observations.
} 
Finally, the post-Bretton Woods era coding uses the de facto classification from Shambaugh (2004), as described above. ${ }^{8}$ We have adopted the terms "peg" and "nonpeg" to describe countries' regimes to emphasize that the countries without pegged rates may not be pure floats; instead, the government may conduct some deliberate exchange-rate management. Roughly half the observations are pegs and half are not, providing plentiful within-era variation.

\section{Individual Country Episodes}

For the PSS analysis, individual country/regime episodes are examined using monthly data. $D e$ facto coding of the exchange-rate regime coding follows much the same pattern as for annual data: we ask if the exchange rate has stayed within $\pm 2 \%$ bands over at least 12 months. Episodes for the gold standard and Bretton Woods eras are listed in Appendix 1. Short episodes of less than three years are excluded as such data series are of insufficient length for reliable time-series estimation. There are 13 defined peg episodes and 7 nonpeg episodes based on de jure status under the gold standard, and 20 pegs and 5 nonpegs based on de facto status. Under Bretton Woods, there are 19 pegs and only one nonpeg (Brazil). The other nonpegs in that era are too brief to include. In addition, in the post-Bretton Woods era, there is a considerable amount of flipping back and forth from peg to nonpeg for many countries. For this era, a separate category of "occasional peg" is created. Occasional pegs have at least 3 short pegs lasting less than three years, and the episode is defined from the start of the pegging until the last peg period ends. To prevent short nonpeg episodes that are really simply the middle of these occasional pegs from being counted as nonpegs, nonpegs must last at least 10 years in the post-Bretton Woods era. There are 70 pegs, 25 occasional pegs, and 32 nonpegs during that era.

\section{Capital Control Status}

For part of the empirical analysis we will want to code countries as either having or not having capital controls. This determination is not straightforward. De facto classifications are difficult to use for a number of reasons. Most are available for a limited number of countries and a limited amount of time. Some rely on interest rate differentials (the phenomenon we study) and thus are not appropriate. While de jure codes are available for many countries, they are available only

\footnotetext{
${ }^{8}$ Shambaugh (2004) provides an extensive discussion of different options from IMF coding to other de facto classifications. Recent work by Reinhart and Rogoff (2004) uses data on parallel market exchange rates to classify the currency regime, and thus is not directly relevant for the present inquiry. Regimes with parallel rates rely on capital controls to ensure exchange-market separation, so the exchange rate's behavior need not constrain monetary policy. Interestingly, however, our basic results still hold even if we use the Reinhart-Rogoff coding.
} 
after 1973. We proceed by assuming that all countries have open capital markets during the gold standard era, that none do during Bretton Woods, and that the official IMF coding from the Exchange Rate Arrangements yearbooks is a reasonable approximation for measuring the use of capital controls during the post-Bretton Woods era. ${ }^{9}$

\section{Persistence in Interest Rates}

Figures 1a, 1b, and 1c display base interest rates during the three eras that we study. On visual inspection, the gold-standard UK interest rate appears to be far more stationary than the US postwar interest rates, as expected. Simple statistical tests back up the ocular evidence: firstorder autocorrelations are much lower under the gold standard, as the table below shows.

\begin{tabular}{lccc}
\hline & Gold Standard & Bretton Woods & Post-Bretton Woods \\
\hline $\begin{array}{l}\text { Autocorrelation coefficient for local } \\
\text { rates }\end{array}$ & 0.82 & 0.94 & 0.92 \\
$\begin{array}{l}\text { Autocorrelation coefficient for base } \\
\text { rates }\end{array}$ & 0.80 & 0.98 & 0.96 \\
\hline
\end{tabular}

Proceeding more rigorously, we applied the unit root tests of Elliot, Rothenberg and Stock (1996), using the modified AIC of Ng and Perron (2001). Only over certain subsamples do these tests reject a unit root. Over the full gold standard period we reject a unit root in the UK interest rate (at the $95 \%$ confidence level). For the US Treasury bill rate, one rejects the unit root null for the full 1948-73 sample, but not based on the 1959-70 sample that we use in our regressions. Over the full post-Bretton Woods era, in only $1.6 \%$ of the episodes can a unit root be rejected for the base interest rate. Local rates follow a similar pattern. In 8 of the 25 goldstandard episodes, one rejects a unit root in the local interest rate (including rejections for all of the long series). But one cannot reject a unit root in any of the 21 Bretton Woods episodes at the $95 \%$ confidence level, and one can reject a unit root in only 5 of 127 post-Bretton Woods episodes. ${ }^{10}$

\footnotetext{
${ }^{9}$ After 1995, the IMF switches from a binary coding (line E2) to a disaggregated coding. Following Shambaugh (2004) we use changes in the disaggregated coding and descriptions in the yearbooks to determine changes in the binary codes. The IMF coding is very similar to the disaggregated coding of Quinn (1997) when data are available for both.

${ }^{10}$ Use of an ADF unit root test generates a similar pattern as those above with a slightly higher number of rejections. Likewise, using the Ng-Perron sequential $t$-test rather than the MAIC allows a few more rejections in the gold standard era. The post Bretton Woods era are generally so far from rejecting a unit root that lag length is irrelevant.
} 
These observations motivate our discussion of econometric methodology below.

\section{Methodology}

Alternative specifications could be used to test the degree to which a local country's interest rate follows a canonical base country's interest rate. The time series properties of the data are quite important in assessing these alternatives. Nominal interest rates tend to be statistically indistinguishable from unit-root processes in limited data samples. They are not literally unitroot processes. If they were, some series would wander into negative territory and others would rise unboundedly, behavior that we do not observe in practice. ${ }^{11}$ Given the low power of most unit root tests ${ }^{12}$ and the need to use relatively short time series in some cases to isolate individual currency episodes, we cannot posit unambiguously the stationarity properties of the data. Thus, we pursue alternative modes of analysis under different assumptions.

If the data are nonstationary or nearly so, any simple regression of the levels of one series on another leaves open the possibility of spurious regression (Granger and Newbold 1974; Phillips 1988). An appropriate approach would then be to difference the data and examine a simple equation such as:

$$
\Delta R_{i t}=\alpha+\beta \Delta R_{b i t}+u_{i t}
$$

where $R_{i t}$ is the local interest rate at time $t, R_{b i t}$ is the base rate at time $t$, and $\Delta$ is the difference operator. This is also a useful specification when the interest rate data are highly persistent and have a long run relationship. For example, suppose that uncovered interest parity holds, with the nominal international interest differential the sum of a statistically stationary expected depreciation rate and a stationary risk premium. Then a regression in interest-rate levels must yield a slope coefficient approaching unity as the sample size rises, regardless of the extent to which the nonbase country exercises its short-run interest-rate independence. A regression in differences such as (1), however, will measure that exercise of independence even in a large sample.

\footnotetext{
${ }^{11}$ As Stanton (1997) observes, nominal rates seem to behave like nonstationary processes until they reach very high or very low levels, at which point there is some mean reversion. See also Wu and Zhang (1997).

${ }^{12}$ Caner and Kilian (2001) show that tests with stationarity as the null are likely to entail spurious rejections when the data are stationary but highly persistent.
} 
With perfect capital mobility and an exchange rate permanently and credibly pegged within a band that is literally of zero width, we would expect to find $\beta=1$ above: home and base-country interest rates would always move one-for-one, and the pegging country's monetary independence would be nil. Otherwise, we would find $\beta<1$ if the home monetary authority uses its monetary independence to offset base interest-rate shocks but $\beta>1$ if it reinforces them.

The data are in panel form, but fixed country effects are not employed in applying (1) because such an effect would assume a constant rate of change in the interest rate for an individual country, a highly unlikely scenario. ${ }^{13}$ The response to a change in the base rate may not be immediate and may vary across countries, so the results of estimating (1) on the pooled sample using high-frequency (monthly) data are quite unclear. At an annual frequency, though, there appears to be sufficient similarity across the countries to allow for the pooling of year averages of monthly data. ${ }^{14}$ We therefore adopt that approach. While this basic specification cannot tell us much about the dynamics of the relationships nor about individual country episodes, it can at least inform us about general patterns across the different eras and across exchange rate regime types. ${ }^{15}$

\section{Dynamic Specification}

We also examine the dynamics of individual country/exchange rate regime episodes and test for the presence of significant levels relationships between domestic and base interest rates. One approach might be to estimate an error-correction model, assuming that the two interest rates are I(1) and cointegrated. Given uncertainty over the order of integration of the interest rates, however, the technique developed by Pesaran, Shin, and Smith (2001), henceforth PSS, and also used in Frankel, Schmukler, and Serven (2002), is quite helpful. The main advantage of the PSS approach is their provision of the different critical values that apply in the $\mathrm{I}(0)$ and $\mathrm{I}(1)$ cases.

\footnotetext{
${ }^{13}$ Likewise one could question the need for any constant term in equation (1). In practice, however, the estimated constant for this equation was very close to zero.

${ }^{14}$ This also means that if some of the series are cointegrated with the base rate, the differences specification is less problematic for annual data as the dynamic adjustments are likely to have settled down to a large extent after a year. In practice, the differences regressions do not show autocorrelation (as one might fear if the series are cointegrated) only pooled OLS levels regressions do (not reported).

${ }^{15}$ There are, of course, many other factors one could expect to affect the degree to which a country follows the base country interest rate. Common shocks, world or regional trade shares, capital controls, level of industrialization, level of debt, etc. could all have some impact. Shambaugh (2004) considers the impact of these factors in studying the post-Bretton Woods era. With the exception of capital controls, which are quite important, the exchange-rate regime tends to be the major determinant of how closely a country follows the base interest rate. This relationship is robust to adding controls for time, trade share, world interest rates, debt exposure, and level of industrialization.
} 
Using the PSS methodology, one can test a specification like the error correction form, but consult the critical values provided by PSS to test the significance of a levels relationship between interest rates without necessarily assuming their order of integration. Thus, if the test statistic either surpasses both critical values or falls short of both critical values, we can either reject the null (of no long-run levels relationship between interest rates) or not without having to take a stand on the order of integration. Only when the test statistic is in the intermediate range must we know the order of integration to make judgments about the data. ${ }^{16}$

To employ the PSS test, we adopt the specification

$$
\Delta R_{i t}=\alpha+\beta \Delta R_{b i t}+\theta\left(c+R_{i, t-1}-\gamma R_{b i, t-1}\right)+u_{i t},
$$

where we can include lags of $\Delta R_{b i t}$ and $\Delta R_{i t}$ as necessary. Above, $\gamma$ is a cointegrating coefficient in the I(1) case; in general, we refer to it as the levels relationship. Following PSS, we test the significance of the adjustment speed $\theta$ to determine whether there is a significant long-run levels relationship. If the local interest rate adjusts to restore the equilibrium relationship after shocks to the base interest rate, we would find $\theta<0$. The size of the coefficient shows the speed of adjustment, with $\theta=-0.5$ in equation (2) implying a half-life of one month. ${ }^{17}$

\section{Effects of Exchange-Rate Bands: What Should We Expect to Find?}

In practice, "fixed" exchange rates are fixed only up to a possibly narrow fluctuation band; our methodology for selecting de facto pegs has allowed for this. As a result, even under a perfectly credible peg, $\beta$ could conceivably be below or above 1 . How big could the divergence from 1 be? We have experimented with simulations of an extension of Krugman's (1991) target zone model, using Svensson's (1991) term-structure model to derive interest rates for noninfinitesimal maturities when the fluctuation band is quite narrow $( \pm 1 \%)$. These simulated rates can then be used to carry out regressions of the form given by equation (1). Appendix 2 describes our simulation methodology in detail. Even under the gold standard, the gold import and export

\footnotetext{
${ }^{16}$ It is difficult to try to analyze the pooled sample with PSS or EC techniques as the data are quite unbalanced with certain countries pegging at certain times and not others. Furthermore, the short-run dynamics appear to differ widely across countries, making pooling questionable.

${ }^{17} \mathrm{We}$ also report the adjustment speeds obtained if one estimates an error correction form simply imposing a cointegration coefficient or levels relationship of $\gamma=1$ (which it should be asymptotically if the series are I(1) and cointegrated).
} 
points defined narrow fluctuation bands for exchange rates. In using the gold standard period as a benchmark for across-era comparisons of interest-rate independence, we will have greater confidence in interpreting the findings if the empirical interest-rate relationships line up with the predictions of a basic theoretical model.

For this application, we approximate Krugman's continuous-time model by assuming a first-order autoregression (with no deterministic drift) for the stochastic "fundamentals" process determining the exchange rate. As in Krugman (1991), the fundamentals for the domestic currency price of foreign exchange would include the relative (domestic less foreign) money supply and other variables, with a rise in the relative domestic money supply raising the relative domestic-currency price of foreign currency (a domestic depreciation). The reason for assuming a mean-reverting fundamentals process, rather than the random walk assumed by Krugman (1991), is to allow a meaningful comparison of interest relationships under a target zone with those under a freely floating exchange rate. (Under a driftless random-walk fundamentals process, domestic and base interest rates would always be equal in a float.) Parameters assumed are described in Appendix 2. As in Svensson (1991), we calculate the domestic interest rate for maturity $m$ and current fundamentals $x$ by adding to the foreign interest rate the expected depreciation rate over the term of the loan.

A key parameter is in the simulations is $\rho\left(\Delta z, \Delta R_{b}\right)$, the correlation between innovations $\Delta z$ in the domestic fundamentals process and innovations in the base foreign interest rate. For example, let $x=m-m_{b}$, the difference between domestic and foreign money supplies. In that case, a positive value for $\rho\left(\Delta z, \Delta R_{b}\right)$ implies a tendency for the domestic central bank to increase the relative domestic money supply whenever foreign interest rates rise. That response implies a smaller increase in the domestic interest rate than the point-for-point rise that would occur were $m-m_{b}$ held constant (the latter outcome being the mean tendency in the case $\rho\left(\Delta z, \Delta R_{b}\right)=0$ ). In the simulations that we illustrate below, we alternatively assume that $\rho\left(\Delta z, \Delta R_{b}\right)=0.5$, which we interpret as partial interest rate smoothing, and $\rho\left(\Delta z, \Delta R_{b}\right)=0.8$, aggressive interest rate smoothing. ${ }^{18}$ The simulations are for overnight interest rates; we have also carried out simulations on three-month rates, which tend to be more tightly linked.

\footnotetext{
${ }^{18}$ Conversely, a negative $\rho$ would imply that domestic monetary policy reinforces the foreign interest rate shock, as under the supposed "rules of the game" of the classical gold standard. The results we find below are consistent with the modern view that these classical rules were not always followed in practice, even before 1914; see Bloomfield (1959) for a pioneering study.
} 


\begin{tabular}{|c|c|c|c|c|c|c|}
\hline $\begin{array}{l}\text { Overnight interest } \\
\text { rates }\end{array}$ & $\begin{array}{l}\text { Target } \\
\text { zone } \\
\text { mean est. } \beta\end{array}$ & $\begin{array}{l}\text { Target zone } \\
\text { median est. } \\
R^{2}\end{array}$ & $\begin{array}{l}\text { Free float } \\
\text { mean est. } \beta\end{array}$ & $\begin{array}{l}\text { Free float } \\
\text { median est. } \\
R^{2}\end{array}$ & $\begin{array}{l}\text { Target } \\
\text { zone mean } \\
\text { est. } \theta\end{array}$ & $\begin{array}{l}\text { Free float } \\
\text { mean est. } \\
\theta\end{array}$ \\
\hline$\rho\left(\Delta z, \Delta R_{b}\right)=0.5$ & $\begin{array}{c}0.56 \\
(0.12)\end{array}$ & 0.12 & $\begin{array}{c}0.37 \\
(0.09)\end{array}$ & 0.05 & $\begin{array}{l}-0.21 \\
(0.07)\end{array}$ & $\begin{array}{l}-0.08 \\
(0.03)\end{array}$ \\
\hline$\rho\left(\Delta z, \Delta R_{b}\right)=0.8$ & $\begin{array}{c}0.34 \\
(0.15)\end{array}$ & 0.05 & $\begin{array}{c}0.00 \\
(0.08)\end{array}$ & 0.00 & $\begin{array}{l}-0.22 \\
(0.08)\end{array}$ & $\begin{array}{l}-0.08 \\
(0.04)\end{array}$ \\
\hline
\end{tabular}

We see that $\beta$ coefficients well below 1 are likely to arise when domestic authorities partially smooth short-term domestic interest rates, notwithstanding the enforcement of a narrow target zone for the exchange rate. ${ }^{19}$ Interestingly, though, for the same value of $\rho\left(\Delta z, \Delta R_{b}\right)$, the $\beta$ can remain quite high even under a free float (albeit lower than under the target zone). Thus, moving from a target zone to a float reduces $\beta$ from 0.56 to 0.37 in the simulations for $\rho\left(\Delta z, \Delta R_{b}\right)$ $=0.5$. As we would expect, a higher value of $\rho\left(\Delta z, \Delta R_{b}\right)$ can reduce $\beta$ substantially under any currency regime. ${ }^{20}$ The simulation results underscore the importance of having the classical gold standard (itself a target zone system because of gold points) as a quantitative benchmark for results from later periods. Because the gold standard is widely acknowledged to be an era in which the exercise of monetary independence was limited, results that look similar to those found in pre-1914 data, even if they entail a $\beta$ below 1, can be construed as supporting the hypothesis that pegs greatly limit monetary autonomy. ${ }^{21}$

\footnotetext{
${ }^{19}$ Of course, Krugman's model assumes effectively infinite foreign reserves, a factor that may exaggerate the ability of some countries to smooth the path of domestic interest rates. On the other hand, exchange rate bands introduce the possibility of risk premia in interest rates (deviations from uncovered interest parity), although these are likely to be small for narrow bands and we do not model them.

${ }^{20}$ For $\rho\left(\Delta z, \Delta R_{b}\right)=0$, the mean $\beta$ is essentially 1 under the target zone or the float, as expected. For $\rho\left(\Delta z, \Delta R_{b}\right)<0$, the mean $\beta$ exceeds 1 and is relatively higher under the float.

${ }^{21}$ Thus, a $\beta$ below 1 is not sufficient for substantive monetary independence. We caution the reader that it is not strictly necessary either. An economy buffeted by permanent real shocks, for example, will be stabilized by a floating exchange rate even if its interest rate never deviates from the foreign rate. An important (and unanswered) question is whether independence at the short end of the term structure but not at the long end, as in a fairly narrow target zone, confers on a central bank much leverage over the economy. Some scholars of the gold standard argue that the gold points allowed considerable monetary independence, a contention that, if true, would make the gold standard an unacceptable benchmark for judging the degree to which a pegged exchange rate binds monetary policy.
} 
We have also estimated the equation in interest-rate levels corresponding to (1) using the simulated data. In all cases, mean estimates of $\beta$ are substantially closer to 1 , as econometric theory would lead us to expect, and they move closer to 1 as we increase the length of the simulated data series. These latter findings suggest that, due to the high persistence of nominal interest rates and their tendency to trend together, levels regressions contain less information about monetary independence than do regressions in differences.

The final two columns of the preceding table report simulated mean estimates of the PSS adjustment-speed parameter, $\theta$. The estimate under a target zone is about $20 \%$ per month, significantly faster than the estimated $8 \%$ per month under a float. The mean values seem insensitive to the underlying value of the short-run policy response parameter $\rho\left(\Delta z, \Delta R_{b}\right)$.

\section{Discussion of Findings}

The broadest characterization of the data comes from pooling nonoverlapping annual differences of year-averaged monthly interest rates. This specification measures the extent to which, on average across countries, a change in the base interest rate is followed abroad in the same year.

The results of estimating equation (1) are shown in Table 1, which reveals striking differences across the time periods. If we simply pool data within periods, with no distinction across exchange-rate regimes, we see that the gold standard and post-Bretton Woods eras have fairly similar slope coefficients $\beta$ (0.42 and 0.36, respectively), especially when compared to the Bretton Woods era $(-0.20){ }^{22}$ The big difference between the gold standard and the current era appears in the $R^{2}$, where gold standard base-rate changes can explain a comparatively large fraction of local-rate changes, but modern base rate changes cannot $\left(R^{2}=0.26\right.$ versus 0.03 , respectively). For the Bretton Woods era the $\beta$ coefficient is indistinguishable from zero and the $R^{2}$ is only 0.02 , showing that the capital controls of the era seem to have essentially shut down the mechanism by which local countries are forced to follow the base country. In many cases, of course, those controls allowed governments to administer domestic interest rates.

While there are not enough nonpeg episodes under Bretton Woods to examine the nonpegs separately, the pegs and nonpegs do appear to behave quite differently in both the gold standard and modern eras. The coefficients (and associated standard errors) on the base rate are

The dynamic cointegration results we report below throw doubt, however, on the hypothesis of substantial monetary independence under gold. 
similar for pegs in the two eras, both are similar to the simulation results reported earlier, and both are significantly higher than the nonpegs. More notably, the $R^{2}$ for the pegs is 0.41 in the gold standard and 0.19 for the modern era compared to 0.00 and 0.01 , respectively, for the nonpegs. This sharp contrast indicates a large difference in the extent the base rate can explain the behavior of local rates. The much higher $R^{2}$ under gold standard pegs is striking, and greatly exceeds the median simulated value for a narrow target zone. The empirical estimate, reflecting fewer interest rate changes for reasons other than following the base rate, could reflect a lower variance of fundamentals under the gold standard, or less use of the independence conferred by bands. It could also reflect the relatively greater credibility of gold standard exchange rate commitments or the more frequent presence of capital controls in the modern era, although we can draw no firm conclusions without further investigation.

In neither era do we see slope coefficients or $R^{2}$ s close to 1 , which a model with no exchange rate bands, costless arbitrage, and perfect regime credibility would imply. Instead we see results more consistent with a tight target zone. The simulation provides a benchmark and shows that a $\beta$ of 0.5 to 0.6 and $R^{2}$ s of around 0.1 to 0.2 are consistent with a target zone with little exchange-rate variation. Looking at the gold standard results and simulation, we should not be surprised by the somewhat low slope coefficients and $R^{2}$ s that we find for pegs in the current era. As we have noted, even in the essentially capital-control free era of the gold standard, pegged countries' interest rates did not show a perfect correlation with the base interest rate due to exchange rate movements within the gold points, which gives latitude for short-term interestrate divergence (Svensson 1994). Now as then, most exchange rates that we consider to be pegged actually do move within specified narrow bands.

A second contrast between the gold standard and modern eras appears in examining the nonpegs. Gold-standard de facto nonpegs on average show almost no connection to the base rate $\left(\beta=0.05\right.$, standard error $\left.=0.09, R^{2}=0\right)$, while the slope coefficient for the modern era is much closer to that for the pegs $(\beta=0.27)$. The modern (post-Bretton Woods) nonpeg $R^{2}$ is still quite low (0.01), implying substantial variation independent of the base rate, but the gap between the peg and nonpeg slope coefficients is not nearly as large for the modern era as under the gold standard. $^{23}$

\footnotetext{
${ }^{22}$ We refer in the text to the de facto results, though de jure results are always reasonably close.

${ }^{23}$ It should be noted that some interest rate series in the modern era are entirely flat (see Shambaugh 2004). When these rates are excluded, the results for modern pegs become $\beta=0.59$, standard error $=0.04, R^{2}=0.26$, and for
} 
This point is seen more sharply when one pools the data and includes and interaction term for pegging times the base interest rate:

$$
\Delta R_{i t}=\alpha+\beta \Delta R_{b i t}+\beta_{2} P E G_{i t} \Delta R_{b i t}+u_{i t}
$$

While under the de facto gold standard, $\beta$ is close to zero (0.05) and does not differ statistically from zero (standard error $=0.10$ ), the coefficient on $\beta_{2}$ in equation (3) is $0.47(0.09)$. With postBretton Woods data, $\beta$ is estimated as $0.26(0.08)$ and $\beta_{2}$ as $0.19(0.09) .^{24,25}$

The general message from these tests is that the exchange rate regime does affect the extent to which a country follows the base, but that the capital controls of the Bretton Woods era seemed to significantly slow or even stop those reactions. The results from the gold standard shed some light on the modern findings. They show that we should not be surprised to find a slope coefficient $\beta$ or an $R^{2}$ that is distant from 1. Our comparison with the gold standard also shows, however, that the nonpegs of the post-Bretton Woods era to respond more strongly to changes in the base than was true of nonpegs before 1914. No doubt this finding results from policies meant to limit exchange-rate induced redistributions -- a matter of less government concern before 1914.

In general, the within-era information points to a significant influence of the exchangerate regime on the extent to which a country shadows the base interest rate. Conversely, the across-era comparisons help show the role of capital controls and of different attitudes toward macro-management. As a final check, we pool the eras and test directly the importance of the exchange rate regime and capital control status. These results are reported in Table 2.

First, we divide the sample into pegs and nonpegs, and then capital controls and no capital controls. Looking first at the exchange rate regime, we still see a stark difference between pegs and nonpegs with coefficients of 0.43 vs. 0.26 and $R^{2}$ s of 0.17 vs. 0.01 . Similarly, we see an

modern floats, $\beta=0.28$, standard error $=0.08, R^{2}=0.01$. Thus, removing these mostly small Caribbean countries increases the gap between the two and raises the $R^{2}$ on the pegs.

${ }^{24}$ Again, excluding the interest rates which are constant over the entire modern sample generates $\beta_{1}=0.31(0.08), \beta_{2}$ $=0.27(0.09)$.

${ }^{25}$ While one obviously cannot compare $R^{2}$ across regime when the data is pooled, we can regress the estimated errors on the dummy for peg status to see if the errors vary with exchange rate regime. As expected, the errors are in fact larger for nonpegs as a model using the base interest rate simply does not predict changes in the nonpegged countries' interest rates very well. In the pooled regressions for the de facto gold standard regime and de facto post Bretton Woods era, when the errors are regressed on the peg status, the coefficient is negative and significantly different from zero at $99 \%$ the confidence level. 
impact of capital controls with non-capital control countries showing a coefficient of 0.56 and $R^{2}$ of 0.10 and capital control countries showing a coefficient of 0.26 and $R^{2}$ of 0.01 . Thus, both legs of the trilemma appear to be validated. Tables $2 \mathrm{~b}$ and $2 \mathrm{c}$ test more carefully the interaction of these two sides.

While, as expected, pegs with open capital markets have the highest coefficient and $R^{2}$, there is some evidence of what today has been called "fear of floating" (Calvo and Reinhart 2002), because open capital market nonpegs have a coefficient of 0.53 compared to the pegs' 0.61. On the other hand, the $R^{2}$ still shows a considerable gap with pegs having $R^{2}=0.30$ and floats $R^{2}=0.06$. Thus, despite moving with the base country to some extent, only a small portion of the changes in the floats' interest rates can be explained by changes in the base rate. In addition, we do not find that capital controls are completely isolating. Pegs with capital controls have higher slope coefficients and $R^{2}$ s than the nonpegs with closed markets.

The pooled data show that both the exchange rate regime and capital controls matter (Table 2c), though in columns 1 and 2, capital controls appear to be more important. Once again, removing the countries in the modern era for whom interest rates never change (and thus appear to be purely administered nonmarket rates) increases the importance of the peg variable (columns 3 and 4). ${ }^{26} \mathrm{We}$ also see in columns 2 and 4 that the impact of capital controls and exchange rate regimes are not purely additive as the coefficient on the interaction of the two is estimated to be negative. Either policy will provide a degree of independence and adding the second increases the independence, but not by as much as the policy on its own.

Overall, this evidence supports a modified view of the trilemma for the modern era. Both the exchange rate regime and capital controls clearly affect autonomy, but the combination of floating with capital controls seems to provide unfettered autonomy and removing either limits autonomy to some degree. Nonpegs with open markets and pegs with closed retain some interest-rate autonomy, and, as expected, pegs with open markets have the least of all.

\section{Levels Analysis}

Finally, we can learn considerably more about the relationships of local to base countries by examining specific individual country relationships and estimating testing both the levels

\footnotetext{
${ }^{26}$ Again, regressing the errors on the exchange rate and capital control regime dummies confirms the findings on explanatory power seen in the $R^{2}$ differences in the divided sample regressions. In all four columns, observations with pegs and open capital markets are associated with smaller errors as they can be better explained by the base
} 
relationships between interest rates ( $\gamma$ in equation (2)) and the dynamic adjustment speed $(\theta)$. Rather than assuming a levels relationship exists and estimating it, we test for the presence of level relationships and examine the dynamics of the system. Table 3 shows the results for individual-country regime episodes as well as averages across pegs and nonpegs by era.

In the case of the gold standard, we see that in only two cases are we forced to assume the order of integration as in all others the test statistic for $\theta$ either passes both critical values or fails to do so. Looking at both the de jure and de facto gold standard classifications, we see that there were nonpeg episodes that demonstrate considerable independence. Perhaps the clearest evidence comes from the fact that the levels relationships $\gamma$ have negative signs, implying that rates moved opposite one another over the long run, for two of the seven nonpegs in the de jure classification and all five under the de facto classification. These backwards levels relationships make the average half lives problematic as an indicator of how closely these countries followed the base: many of the nonpegs moved away from the base. The nonpegs of Portugal, Russia, and Spain (all de facto and de jure) show considerable independence from the UK interest rate before 1914.

At the same time, there certainly were some countries that exhibited "fear of floating." Despite not being on the gold standard de jure and thus officially being a nonpeg, some countries followed the base interest rate quite closely. In the case of the Netherlands, 1870-75, the exchange rate is in fact pegged despite no announcement, so it is unsurprising to see the interest rate move so tightly with the base. Austria de facto pegged on and off during its official nonpeg period (1870-92), and it too shows a reasonably tight relationship with the base. ${ }^{27}$

In general, the pegs show little independence. With the exception of India's early pegging experience, all episodes show the expected sign for $\gamma$, and adjustment, measured by $-\theta$, tends to be quick. The only episodes with very slow adjustment (Spain's early de facto peg and Portugal's early de facto peg) are short ones. Long-time gold standard members show levels relationships ranging from 0.4 to 0.6 and adjustment half-lives between two and five months.

interest rate. Coefficients on the peg dummy or the capital control dummy (or a combination) are always negative and significantly different from zero at better than the $99 \%$ confidence level.

${ }^{27}$ Readers may notice a large difference between the estimates of $\gamma$ for India's de facto and de jure nonpegs despite a difference of only 18 observations. Early in India's de jure float, there were some large changes in the interest rate that affect the results. India was in a de facto peg at the time and thus these observations are not in the de facto nonpeg. In addition, this episode is quite sensitive to the lag length chosen. While the standard deviation of the levels estimate across different lag specifications is no more than 0.02-0.05 for most episodes, it is quite large (over 1) for the Indian float. 
The fact that the levels relationship is far less than unity in most cases may seem odd until one considers the era. Because the UK interest rate always resided within reasonably small bands, countries could partially adjust to the UK rate change and use the margin afforded by the gold points and arbitrage costs to cover the rest. If the UK rate continued long in one direction, a foreign country would eventually have to adjust fully, but because the UK rate reverted toward its mean, the estimated level relationship can be less than one. This reflects the constrained interest-rate independence in exchange-rate target zones of the kind described by Svensson (1994). At the same time, though, countries had to move quite quickly to carry out at least some adjustment to any change. Should one consider a levels coefficient of 0.6 and a half-life to shocks of under three months to be evidence of monetary independence under the gold standard? Given the insignificant levels relationships and/or half-lives of over a year that are found in some nonpegs, we would judge that pegs did not have extensive independence under the gold standard, consistent with the prediction of the trilemma.

If one imposes a long-run levels coefficient $\gamma$ of unity, then the adjustment speeds appear to slow down because in truth, the rates never did fully adjust. Thus, Bordo and MacDonald's (1997) depiction of monetary independence under the gold standard due to slow adjustment speeds may require re-examination. (Their study covered only the UK, France, and Germany, with a data set starting in 1880.) By assuming nonstationarity in the gold standard interest-rate data and imposing a unit cointegration coefficient between national rates (consistent with their estimates), the Bordo-MacDonald study may give an exaggerated impression of how slow adjustment speeds actually were. In our gold-standard data, most levels coefficients are significantly below 1, and allowing for this apparently raises estimated adjustment speeds. There was some room for independence under the gold standard, but it appears more obviously for countries that were not pegged. Some nonpegs followed the UK rate anyway, but some did not and exhibited their potential for monetary independence.

The Bretton Woods era provides little room for comparison across regime types, since only Brazil is a nonpeg country according to our criteria. Brazil pegged sporadically in 1965-7, so one could either examine just 1968-70 or include the entire period (both results are reported). Brazil certainly shows independence, given an insignificant estimated levels relationship $\gamma$ and a very slow adjustment speed $\theta$ (half-life of over 17 months) over the full period. (The levels relationship is negative over the later period.) At the same time, capital controls appear to have isolated some of the pegs. Jamaica, Japan, Pakistan, and Zimbabwe all have negative levels 
relationships $(\gamma<0)$ and three more countries have insignificantly positive relationships with half lives exceeding a year. Even in some countries where the levels relationship is close to 1 (e.g., Canada and the Netherlands), the adjustment speed implied by $\theta$ is slow enough that the levels relationship is not clearly significant. Barbados, Germany, Sweden, and the UK have levels relationships above 0.5 and half-lives from 3 to 7 months, implying a tighter relationship than even many gold standard pegs. Thus, not all countries were isolated from the US interest rate during Bretton Woods, and it is likely that over time, the insulation weakened (as seen in the eventual collapse of the system). On average, though, for only $20 \%$ of the pegs can we reject the hypothesis that there is no levels relationship. The average adjustment speed for pegs is over nine months, demonstrating far more flexibility than under the gold standard. It was precisely the desire for such added flexibility, of course, that inspired the design of the Bretton Woods system.

There are too many post-Bretton Woods episodes to consider individually, so we report only averages across the three currency regimes. For pegs and occasional pegs, there are very few instances of negative levels relationships; as a result, we would view the averages as more reliable. Interestingly, the estimated values of $\theta$ for the post-Bretton Woods pegs and nonpegs, respectively, are of similar magnitudes to those in the simulations described earlier.

Compared to the other eras, we notice three striking features. The first is that far fewer of the episodes are statistically significant. Not only are fewer significant when assuming I(0) interest rates, but because the data are so close to being nonstationary, one should probably consider the I(1) critical value as the more relevant one. This means that even fewer episodes are significant, especially compared to the gold standard. This finding, though, may result in part from the slightly shorter time spans of the modern episodes.

Second, the adjustment speeds are lower in the post-Bretton Woods era. This is especially true for the nonpegs, for which the average half-life is over 30 months. Over $50 \%$ of the nonpegged episodes show half lives that exceed a year, implying a considerable amount of autonomy. Like the low $R^{2} \mathrm{~s}$ in the differences regressions, these results seem to point to a significant amount of autonomy for floating-rate countries and a substantive difference between pegs and nonpegs. This conclusion stands in contrast to previous work on the subject arguing that only a few large countries can pursue independence, regardless of the exchange-rate regime. The PSS results show even more independence for the nonpegs, though, as the average nonpeg levels relationship $\gamma$ is in fact estimated to be negative. This suggests that on average, long 
nonpegged episodes today show as much independence as those of the gold standard era. ${ }^{28}$ This result is directly opposite to the suggestions of Frankel et al. $(2000,2002)$ and the message of the "fear of floating" literature in general, which argues that floating in a globalized world offers little room for monetary independence. ${ }^{29}$ Pegs are also somewhat slower to adjust than during the gold standard, with an average adjustment speed of $\theta=-0.19$ compared to the de facto gold standard adjustment speed of $\theta=-0.27$. Still, the average adjustment speed under pegs in the current period is faster than under Bretton Woods, and more importantly, much faster for pegs than for nonpegs.

While adjustment speed for pegs is slower for the modern era the under the gold standard, the levels relationships are closer to one. The average for pegs is $\gamma=0.93$, compared to between 0.4 and 0.5 for the other eras. Once again, the explanation may lie in the rapidly moving and near-unit-root base interest rates characterizing the modern period. Even if capital controls are present, if countries do not adjust fully over time, the exchange rate may not last.

The comparison across different eras is illuminating. While the gold standard saw pegs with low levels relationships $\gamma$ but fast adjustment speeds $\theta$, and the modern era has seen countries with slower adjustment speeds but levels relationships closer to 1, the Bretton Woods era had both slower adjustment speeds and lower levels relationships. Comparing the gold standard and modern eras, we see that there appears to be room for nonpegs to have some monetary independence especially, when compared to the fixed exchange rate countries. The high levels relationships for pegs during the current era are a switch from the past. But the adjustment speeds seen today do not necessarily demonstrate the exigencies of modern capital markets, because those speeds in fact appear to be somewhat below those prevailing in the pre1914 past. $^{30}$

While useful for different types of data, the alternative tests seem to lead to similar conclusions. Countries that peg do indeed have less monetary freedom than nonpegs, although

\footnotetext{
${ }^{28}$ While this result may appear to be inconsistent with the differences regressions (which show nonpegs having a tighter bond with the base today than in the past), the incongruity is understandable. The PSS results are only for long-standing nonpegs, while the pooled results include as nonpeg the nonpeg years of countries that flip back and forth.

${ }^{29}$ See Shambaugh (2004) for a more detailed discussion of these results. Borenzstein et al. (2001), using a different methodology and country sample, obtain results on monetary independence that support our conclusions. It is important to note that this does not mean that no declared floats exhibit fear of floating, but that some countries that show actual exchange rate flexibility do exhibit strong monetary independence from the base rate.

${ }^{30}$ It should be noted that the adjustment speeds are not simply lower because the levels relationships are higher. Even when one imposes the level at one, the gold standard data shows a faster adjustment as can be seen on the EC half-life line in the tables.
} 
the capital controls of Bretton Woods did succeed in weakening the linkages among national interest rates. ${ }^{31}$ In addition, despite gold points and less sophisticated arbitrage and communications technologies, pegged countries under the gold standard arguably had even less freedom than do pegged countries today.

It must be acknowledged that we cannot speak to the ways in which intent of the monetary authorities underlies the preceding evidence on interest-rate independence. It is possible that common shocks, not the constraint of the exchange rate regime, make interest rates move together under pegs, and that fixed rates are adopted precisely when such common shocks dominate. Evidence in Shambaugh (2004) suggests that common shocks are not behind the correlation of pegs' interest rates after 1973, but without a fully specified model of monetary authorities' intentions -- and data sufficient to test it -- we can do little more than acknowledge the caveat and move on.

\section{Conclusion}

The overall lesson of our analysis is that the trilemma makes sense as a guiding policy framework. Exchange rate pegs do result in a substantially closer connection to the base country interest rate than do nonpegs. The interest rates of pegged economies react more to changes in the base rate; the base rate can explain more of the changes in the local rate for pegs; and, the pegs react more quickly and have a stronger long run relationship to the base than do nonpegs. Absent capital controls, countries choosing to peg lose considerable monetary independence. At the same time, nonpegs appear to have a reasonable amount of autonomy even when there are no capital controls. Pegs are rarely completely handcuffed (in any era) though, because of exchange rate bands and, possibly, arbitrage costs. Conversely, nonpegs are never purely free floats, as even countries that are not pegging their currencies do often choose to follow the base interest rate to some degree.

The results also show some interesting perspectives across eras. Pegs in both eras of open capital markets show fairly similar relationships with the base interest rate. In particular, pooled regressions look somewhat similar, though the $R^{2}$ for the gold standard is always higher. In line with conventional wisdom, the gold standard was not an era with extensive independence for the pegged countries. The pooled slope coefficients on base interest-rate changes are strongly

\footnotetext{
${ }^{31}$ Shambaugh (2004) finds that capital controls are quite important in distinguishing the degree to which a country
} 
positive, and adjustment speeds faster, in the gold standard era. The gold standard is a useful benchmark from which to judge the relationships between countries today. We see that slope coefficients and $R^{2}$ for pegs significantly below unity should not be a surprise. These results also match our target zone simulations, which again show that we should not expect slope coefficients and $R^{2} \mathrm{~s}$ for pegs to equal one even if the target zone is quite narrow.

Based on the differences regressions, the nonpegs of today do appear to have interest rates more tightly linked to base rates than in the past (especially absent capital controls). But there are many countries, not just a few large ones, that consistently move their interest rates in ways that imply no long-run levels relationship with the base and show much slower adjustment to shocks. The longer run nonpegs that are used as episodes show a very weak connection to the base with negative or insignificant levels relationships and slow adjustment. The fact that there are a few examples of countries exhibiting "fear of floating" under the gold standard strengthens the argument that it is not that nonpegs cannot exert independence (for some certainly could during the gold standard), but that some may simply choose not to do so.

A last lesson is that the designers of the Bretton Woods system achieved their goal of exchange-rate stability with more room for interest-rate autonomy. Despite fairly rigid pegs, the Bretton Woods era shows both weaker levels relationships and slower adjustment speeds to the long run. As capital controls became more porous over the 1960s, the combination of exchange rate pegs and monetary independence became untenable. Despite recent challenges to the trilemma as a concept, we see its lessons borne out over a long span of modern economic history.

follows the base in the modern era as well. 


\section{Appendix 1: Data Availability and List of Episodes}

Gold Standard:

Data available:

$\begin{array}{lcc} & \text { from } & \text { to } \\ \text { France } & 1-1870 & 6-1914 \\ \text { Germany } & 1-1870 & 6-1914 \\ \text { Netherlands } & 1-1870 & 6-1914 \\ \text { Belgium } & 1-1870 & 6-1914 \\ \text { Italy } & 1-1885 & 6-1914 \\ \text { Austria } & 1-1870 & 6-1914 \\ \text { Spain } & 1-1883 & 6-1914 \\ \text { Portugal } & 1-1885 & 6-1914 \\ \text { Russia } & 1-1870 & 8-1900 \\ \text { Denmark } & 5-1884 & 6-1914 \\ \text { US } & 11-1880 & 6-1914 \\ \text { India } & 5-1884 & 6-1914 \\ \text { Switzerland } & 12-1892 & 6-1914 \\ \text { Sweden } & 12-1892 & 6-1914 \\ \text { Norway } & 1-1894 & 6-1914\end{array}$

Gold Standard de jure Episodes

Pegs

\begin{tabular}{lcccc} 
& actual & \multicolumn{2}{c}{ with data available } \\
from & $1-1870$ & to & from & to \\
France & $12-1871$ & $6-1914$ & $2-1872$ & $6-1914$ \\
Germany & $6-1875$ & $6-1914$ & $12-1872$ & $6-1914$ \\
Netherlands & $1-1870$ & $6-1914$ & $6-1876$ & $6-1914$ \\
Belgium & $1-1884$ & $12-1914$ & $1-1870$ & $6-1914$ \\
Italy & $8-1892$ & $6-1914$ & $1-1885$ & $12-1893$ \\
Austria & $1-1870$ & $6-1891$ & $8-1893$ & $6-1914$ \\
Portugal & $1-1873$ & $6-1914$ & $1-1885$ & $6-1891$ \\
Denmark & $1-1879$ & $6-1914$ & $5-1884$ & $6-1914$ \\
US & $1-1898$ & $6-1914$ & $11-1880$ & $6-1914$ \\
India & $1-1870$ & $6-1914$ & $1-1899$ & $6-1914$ \\
Switzerland & $1-1873$ & $6-1914$ & $12-1892$ & $6-1914$ \\
Sweden & $1-1873$ & $6-1914$ & $1-1894$ & $6-1914$ \\
Norway & $1-1897$ & $6-1914$ & $1-1897$ & $6-1914$ \\
Russia & $1-1870$ & $12-1882$ & none & $8-1900$ \\
Spain & & & & \\
Nonpegs & $1-1870$ & $5-1875$ & $3-1871$ & insufficient data \\
Netherlands & $1-1894$ & $6-1914$ & $1-1894$ & $6-1914$ \\
Italy & $1-1870$ & $7-1892$ & $2-1871$ & $7-1892$ \\
Austria & $1-1883$ & $6-1914$ & $1-1883$ & $6-1914$ \\
Spain & $7-1891$ & $6-1914$ & $7-1891$ & $6-1914$ \\
Portugal & $1-1870$ & $12-1896$ & $2-1871$ & $12-1896$ \\
Russia & $5-1884$ & $12-1897$ & $5-1884$ & $12-1897$ \\
India & $1-1870$ & $11-1871$ & insufficient data & \\
Germany & Denmark, US, Australia all end nonpeg periods before data becomes available \\
Sweden, Norway & & & \\
& & & & \\
\end{tabular}




$\begin{array}{lcc}\text { Gold Standard de facto Episode } \\ \text { Pegs } & \text { From } & \text { To } \\ \text { France } & 4-1872 & 6-1914 \\ \text { Germany } & 7-1872 & 6-1914 \\ \text { Netherlands } & 1-1870 & 6-1914 \\ \text { Belgium } & 12-1872 & 6-1914 \\ \text { Italy early peg } & 1-1885 & 2-1892 \\ \text { Italy late peg } & 10-1902 & 6-1914 \\ \text { Austria early peg } & 6-1879 & 8-1888 \\ \text { Austria late peg } & 5-1894 & 6-1914 \\ \text { Spain early peg } & 1-1883 & 1-1890 \\ \text { Spain late peg } & 6-1910 & 5-1914 \\ \text { Portugal early } & 1-1885 & 1-1890 \\ \text { Portugal late peg } & 6-1910 & 5-1914 \\ \text { Russia } & 9-1894 & 8-1900 \\ \text { Denmark } & 5-1884 & 6-1914 \\ \text { US } & 1-1883 & 6-1914 \\ \text { India early peg } & 1-1899 & 3-1903 \\ \text { India late peg } & 5-1904 & 6-1914 \\ \text { Switzerland } & 12-1892 & 6-1914 \\ \text { Sweden } & 12-1892 & 6-1914 \\ \text { Norway } & 1-1894 & 6-1914 \\ \text { Nonpegs } & & \\ \text { Spain } & 8-1891 & 11-1901 \\ \text { Portugal } & 8-1891 & 11-1901 \\ \text { Russia 1 } & 12-1875 & 2-1882 \\ \text { Russia 2 } & 11-1887 & 9-1893 \\ \text { India } & 10-1890 & 12-1897\end{array}$




\section{Bretton Woods:}

All countries are pegged except Brazil (in the early and late 1960's), Canada (1960-61, 5-1970ff), the UK in 1967 and Germany beginning in mid- 1969.

Data available: (annual data is available for most countries for the full 1959-70 period)

$\begin{array}{lccc} & \text { From } & \text { To } & \text { series used } \\ \text { Australia } & 11-1959 & 12-1970 & \text { T-bill } \\ \text { Austria } & 2-1960 & 12-1970 & \text { T-bill } \\ \text { Barbados } & 12-1966 & 12-1970 & \text { T-bill } \\ \text { Belgium } & 1-1959 & 12-1970 & \text { T-bill } \\ \text { Brazil } & 1-1964 & 12-1970 & \text { mon.mkt } \\ \text { Canada } & 1-1959 & 12-1970 & \text { T-bill } \\ \text { France } & 1-1960 & 12-1970 & \text { T-bill } \\ \text { Germany } & 12-1959 & 12-1970 & \text { mon.mkt } \\ \text { India } & 1-1959 & 12-1970 & \text { mon.mkt } \\ \text { Italy } & 1-1959 & 12-1970 & \text { T-bill } \\ \text { Jamaica } & 1-1959 & 12-1970 & \text { T-bill } \\ \text { Japan } & 1-1959 & 12-1970 & \text { mon.mkt } \\ \text { Malaysia } & 2-1961 & 12-1970 & \text { T-bill } \\ \text { Netherlands } & 1-1959 & 12-1970 & \text { T-bill } \\ \text { Pakistan } & 1-1964 & 12-1970 & \text { mon.mkt } \\ \text { South Africa } & 1-1959 & 12-1970 & \text { T-bill } \\ \text { Sweden } & 1-1959 & 12-1970 & \text { T-bill } \\ \text { Switzerland } & 1-1959 & 12-1970 & \text { mon.mkt } \\ \text { Trinidad and Tobago } & 12-1964 & 12-1970 & \text { T-bill } \\ \text { UK } & 1-1959 & 12-1970 & \text { T-bill } \\ \text { Zimbabwe } & 2-1962 & 12-1970 & \text { T-bill }\end{array}$

\section{Post-Bretton Woods Era Country Sample:}

Algeria, Antigua and Barbuda, Argentina, Australia, Austria, The Bahamas, Bahrain, Barbados, Belgium, Belize, Benin, Bolivia, Brazil, Bukina Faso, Canada, Hong Kong, Colombia, Cote D Ivoire, Denmark, Dominica, Dominican Republic, Egypt, El Salvador, Ethiopia, Fiji, Finland, France, Germany, Ghana, Greece, Grenada, Guatemala, Guyana, Haiti, Hungary, Iceland, India, Indonesia, Ireland, Israel, Italy, Jamaica, Japan, Kenya, Korea, Kuwait, Lao People's Dem. Rep, Lebanon, Lesotho, Libya, Luxembourg, Madagascar, Malawi, Malaysia, Maldives, Mali, Malta, Mauritius, Mexico, Morocco, Mozambique, Namibia, Nepal, Netherlands, Netherlands Antilles, New Zealand, Niger, Nigeria, Norway, Pakistan, Papua New Guinea, Paraguay, Philippines, Poland, Portugal, Romania, Senegal, Seychelles, Sierra Leone, Singapore, Solomon Islands, South Africa, Spain, Sri Lanka, St. Kitts and Nevis, St. Lucia, St. Vincent \& Grens., Swaziland, Sweden, Switzerland, Tanzania, Thailand, Togo, Trinidad and Tobago, Tunisia, Turkey, Uganda, United Kingdom, Uruguay, Vanuatu, Venezuela, Zambia, Zimbabwe

Data are available for some or all of the years 1973-2000. More details are available in Shambaugh (2004). 


\section{Appendix 2: Simulating Interest Rates in an Exchange-Rate Target Zone}

In simulating international interest-rate covariation when the exchange rate is confined to a target zone $[\underline{e}, \bar{e}]$, we draw on the basic analysis of Krugman (1991), with some modifications.

In Krugman's model, the time- $t(\log )$ exchange rate $e(t)$ is determined by the equilibrium condition

$$
e(t)=x(t)+\eta \frac{E_{t}\{d e(t+1)\}}{d t},
$$

where $x(t)$ is the $(\log )$ "fundamental" underlying exchange-rate behavior and $\eta$ is the interest semi-elasticity of money demand. Because we wish to compare target zones with unconstrained floating rates, and a random walk for the floating exchange rate would force perfect international correlation of interest rates, we instead assume mean-reverting fundamentals as in Froot and Obstfeld (1991). Fundamentals follow the zero-drift diffusion process:

$$
d x(t)=-\xi x(t) d t+\sigma d z(t) .
$$

The solution for the exchange satisfies the nonlinear ordinary differential equation in $x$,

$$
e(x)=x-\eta \xi x e^{\prime}(x)+\frac{\eta \sigma^{2}}{2} e^{\prime \prime}(x) .
$$

The preceding generalization of Hermite's equation has the general solution 


$$
e(x)=\frac{x}{1+\eta \xi}+A_{1} M\left(\frac{1}{2 \eta \xi}, \frac{1}{2}, \frac{\xi x^{2}}{\sigma^{2}}\right)+A_{2} M\left(\frac{1+\eta \xi}{2 \eta \xi}, \frac{3}{2}, \frac{\xi x^{2}}{\sigma^{2}}, x\right.
$$

where $M(., .,$.$) is the confluent hypergeometric function (of the first kind) and A_{1}$ and $A_{2}$ are arbitrary constants. (Note that this solution corrects the formula reported by Froot and Obstfeld 1991.) The exchange rate bounds determine fundamentals bounds $[\underline{x}, \bar{x}]$ at which intervention to contain the exchange rate occurs. The economically relevant particular solution for $e(x)$ (given by values for $A_{1}$ and $A_{2}$ ) is determined jointly with $[\underline{x}, \bar{x}]$ by the conditions:

$$
\begin{aligned}
& e(\underline{x})=\underline{e}, \\
& e(\bar{x})=\bar{e}, \\
& e^{\prime}(\underline{x})=0, \\
& e^{\prime}(\bar{x})=0 .
\end{aligned}
$$

Because the problem is symmetric when the drift in fundamentals is zero, $A_{1}=0$. In the simulations we assume a currency band of \pm 1 percent, that is, $[\underline{e}, \bar{e}]=[-0.01,0.01]$. Of course, the above solution describes a freely floating exchange rate when $A_{1}=A_{2}=0$.

Instantaneous interest differentials equal instantaneous expected currency depreciation rates. As the interest rates we use in our empirical analysis have noninfinitesimal maturities, however, we build on Svensson's (1991) model of the term structure in a target zone to derive interest rates on longer-dated instruments. Let $f(m, x)$ denote the exchange rate expected to prevail after a time interval of length $m$ has elapsed, given current fundamentals of $x$ (where $m$ is a fraction of a year). Svensson (1991) approximates the annualized interest differential (home less foreign) at maturity $m$ by

$$
\delta(m, x)=\frac{f(m, x)-e(x)}{m}
$$


and shows further that $f(m, x)$ satisfies a partial differential equation (the heat equation) that in the present context would be written as

$$
f_{m}(m, x)=-\xi x f_{x}(m, x)+\frac{\sigma^{2}}{2} f_{x x}(m, x) .
$$

The relevant particular solution invokes the boundary condition $f(0, x)=e(x)$ as well as zeroslope conditions at $[\underline{x}, \bar{x}]$, for all $m$, identical in form to those used to solve for $e(x)$ (see Svensson 1991 for details). This partial differential equation is solved numerically for a mesh of $100 x$ values in $[\underline{x}, \bar{x}]$ including the edges, and a mesh of three values for $m$, zero and the inverses of the two interest-rate maturities considered (overnight and three months).

In practice the simulations adopt a finite, brief time interval of 10 minutes and approximate the diffusion process driving the fundamentals by the difference equation

$$
x_{t+h}-x_{t}=-\xi x_{t} h+\sigma \sqrt{h}\left(z_{t+h}-z_{t}\right)
$$

where the shock $z_{t+h}-z_{t}$ is standard normal and $\sigma^{2}$ is the annual variance of the innovation in fundamentals. (Realizations of $x$ are constrained to stay within $[\underline{x}, \bar{x}]$.) Thus, assuming a 360-day year, $h=1 /(360 \times 24 \times 6)=1 / 51,840$. The innovations in the base interest rate, $R_{b(t+h)}-R_{b t}$, and domestic fundamentals, $z_{t+h}-z_{t}$, are drawn from a bivariate normal distribution. As explained above in the main text, the key parameter of this bivariate distribution is the correlation coefficient between innovations in the base interest rate and in domestic fundamentals, $\rho\left(\Delta R_{b t}, \Delta z_{t}\right)$. That correlation coefficient summarizes the extent to which policy smoothes domestic interest rates in the face of foreign interest-rate shocks. Base interest rates are constrained to be nonnegative. The base interest rate is expressed on an annualized basis. We 
adopt parameter settings under which $\eta=4, \xi=1.5, \sigma=0.11$, and the standard deviation of the annual change in $R_{b t}$ is 0.019 (so that the standard deviation of $R_{b(t+h)}-R_{b t}$ is $0.019 \times$ $\left.(51,840)^{-1 / 2}\right)$.

To bring the simulation methodology into line with our empirical specification, we add an exogenous shock $v$ to the domestic interest rate that uncovered interest parity would predict. For annualized rates of maturity $m$,

$$
R_{t}^{m}=R_{b t}^{m}+\delta(m, x)+v_{t}
$$

where the standard deviation of $v$ is 0.002 (that is, 20 basis points). In practice, the addition of the random noise could create a pure arbitrage possibility -- for example, if the domestic interest rate were to exceed the foreign rate by a percentage exceeding the maximum domestic-currency depreciation rate allowed by the band. To avoid this outcome, instead of adding the raw shock $v$ in the preceding interest-rate equation, for the target zone we add the truncated shock

$$
\tilde{v} \equiv \min \left\{\frac{0.01-f(m, x)}{m}, \max \left\{\frac{-0.01-f(m, x)}{m}, v\right\}\right\}
$$

As noted, we model domestic interest rates at the overnight and three-month maturities. To generate our simulated interest-rate data, we sample the base interest rate $R_{b}$ and the fundamental $x$ on the last day of a 30-day month, at the end of hour 8 (the close of the last trading day) and then compute $e(x), f(m, x), \delta(m, x)$, and the domestic interest rate $R^{m}$. We constrain the domestic interest rate to be nonnegative. This procedure gives us 12 yearly observations, and we repeat it over 30 years. The resulting simulated data are then used in the illustrative synthetic regressions. Values reported are based on 1,000 replications. 


\section{References}

Banerjee, A., J. Dolado, J. Galbraith, and D. Hendry. 1997, Cointegration, Error-Correction, and the Econometric Analysis of Non-stationary Data. Oxford: Oxford University Press.

Bloomfield, Arthur I. 1959. Monetary Policy under the International Gold Standard: 1880-1914. New York: Federal Reserve Bank of New York.

Bordo, Michael D., and Ronald MacDonald. 1997. Violations of the "Rules of the Game" and the Credibility of the Classical Gold Standard, 1880-1914. Working Paper Series no. 6115, National Bureau of Economic Research (July).

Bordo, Michael D., and Marc Flandreau. 2003. Core, Periphery, Exchange Rate Regimes, and Globalization. In Globalization in Historical Perspective, edited by M. D. Bordo, A. M. Taylor and J. G. Williamson. Chicago: University of Chicago Press.

Borenzstein, E., J. Zettelmeyer, and T. Philippon. 2001. Monetary Independence in Emerging Markets: Does the Exchange Rate Regime Make a Difference ? IMF Working Paper WP/01/1.

Calvo, Guillermo A., and Carmen M. Reinhart. 2001. Fixing for Your Life. In Brookings Trade Forum 2000, edited by Susan M. Collins and Dani Rodrik. Washington, D.C.: Brookings Institution.

Calvo, Guillermo A., and Carmen M. Reinhart. 2002. Fear of Floating. Quarterly Journal of Economics 117 (May): 379-408.

Caner, Mehmet, and Lutz Kilian. 2001. Size Distortions of Tests of the Null Hypothesis of Stationarity: Evidence and Implications for the PPP Debate. Journal of International Money and Finance 20: $639-57$

Eichengreen, Barry. 1996. Globalizing Capital: A History of the International Monetary System. Princeton, N.J.: Princeton University Press.

Elliot, Graham, Thomas Rothenberg, and James Stock. 1996. Efficient Tests for an Autoregressive Unit Root. Econometrica 64 (July): 813-36

Frankel, Jeffrey A. 1999. No Single Currency Regime is Right for All Countries or at All Times. Princeton University, International Finance Section, Essays in International Finance no. 215 (August).

Frankel, Jeffrey A., Sergio L. Schmukler, and Luis Servén. 2000. Global Transmission of Interest Rates: Monetary Independence and Currency Regime. Mimeo, World Bank, (August).

Frankel, Jeffrey A., Sergio L. Schmukler, and Luis Servén. 2002. Global Transmission of Interest Rates: Monetary Independence and Currency Regime. Working Paper Series no. 8828, National Bureau of Economic Research (March).

Friedman, Thomas L. 1999. The Lexus and the Olive Tree. New York: Farrar Straus Giroux. 
Froot, Kenneth A., and Maurice Obstfeld. 1991. Stochastic Process Switching: Some Simple Solutions. Econometrica 59 (January): 241-50.

Goodhart, Charles A. E. 1989. The Conduct of Monetary Policy. Economic Journal vol. 99 no. 396, pp. 293-346.

Granger, Clive W. J., and Paul Newbold. 1974. Spurious Regressions in Econometrics. Journal of Econometrics 2 (1974): 111-20.

Hawtrey, Ralph. 1947. The Gold Standard. London: Longmans, Green.

International Monetary Fund. Various dates. Annual Report on Exchange Arrangements and Exchange Restrictions.

Krugman, Paul R. 1991. Target Zones and Exchange Rate Dynamics. Quarterly Journal of Economics 106 (August): 669-82.

Levy Yeyati, Eduardo, and Federico Sturzenegger. 2002. Classifying Exchange Rate Regimes: Deeds vs. Words. Universidad Torcuato Di Tella. Photocopy.

Meissner, Christopher M. 2001. A New World Order: Explaining the Emergence of the Classical Gold Standard. U.C. Berkeley. Photocopy.

Neal, Larry, and Marc Weidenmier. 2003. Crises in the Global Economy from Tulips to Today: Contagion and Consequences. In Globalization in Historical Perspective, edited by M. D. Bordo, A. M. Taylor and J. G. Williamson. Chicago: University of Chicago Press.

Ng, Serena, and Pierre Perron. 2001. Lag Length Selection and the Construction of Unit Root Tests with Good Size and Power. Econometrica 69 (November): 1519-54.

Obstfeld, Maurice, and Kenneth Rogoff. 1995. The Mirage of Fixed Exchange Rates. Journal of Economic Perspectives 9 (Fall): 73-96.

Obstfeld, Maurice, and Alan M. Taylor. 2004. Global Capital Markets: Integration, Crisis, and Growth. Cambridge: Cambridge University Press.

Pesaran, M. Hashem, Yongcheol Shin, and Richard J. Smith. 2001. Bounds Testing Approaches to the Analysis of Level Relationships. Journal of Applied Econometrics 16 (May/June): 289-326.

Phillips, Peter C. B. 1988. Regression Theory for Near Integrated Time Series. Journal of Econometrics 56: $1021-43$.

Quinn, Dennis. 1997. The Correlates of Changes in International Financial Regulation. American Political Science Review 91 (September): 531-51.

Reinhart, Carmen M., and Kenneth S. Rogoff. 2004. The Modern History of Exchange Rate Arrangements: A Reinterpretation. Quarterly Journal of Economics 119 (February): 1-48.

Rose, Andrew K. 1996. Explaining Exchange Rate Volatility: An Empirical Analysis of 'The Holy Trinity' of Monetary Independence, Fixed Exchange Rates, and Capital Mobility. Journal of International Money and Finance 15 (6): 925-45. 
Shambaugh, Jay C. 2004. The Effects of Fixed Exchange Rates on Monetary Policy. Quarterly Journal of Economics 119 (February): 301-52.

Stanton, Richard H. 1997. A Nonparametric Model of Term Structure Dynamics and the Market Price of Interest Rate Risk. Mimeo, Haas School of Business, University of California, Berkeley.

Svensson, Lars E. O. 1991. The Term Structure of Interest Rate Differentials in a Target Zone: Theory and Swedish Data. Journal of Monetary Economics 28: 87-116.

Svensson, Lars E. O. 1994. Why Exchange Rate Bands? Journal of Monetary Economics 33: 157-99.

Taylor, Bryan. 2000. Encyclopedia of Global Financial Markets. Global Financial Database.

Wu, Y., and H. Zhang. 1997. Do Interest Rates Follow Unit-Root Processes ? Evidence from CrossMaturity Treasury Bill Yields. Review of Quantitative Finance and Accounting 8: 69-81. 
Table 1. Differences regressions on annual data ${ }^{32}$

Gold Standard de jure classification

\begin{tabular}{lcccc}
\hline & pool & peg & nonpeg & pool \\
\hline \# observations & 499 & 350 & 140 & 490 \\
$\beta$ & $.42^{\text {aa }}$ & $.52^{\text {aa }}$ & $.16^{\text {aa }}$ & $.16^{\text {aa }}$ \\
$\beta$ std error & .03 & .04 & .06 & .06 \\
$\beta_{2}$ & & & & $.36^{\text {aa }}$ \\
$\beta_{2}$ std error & .26 & .36 & .05 & .07 \\
$R^{2}$ & & & .30 \\
\hline
\end{tabular}

Gold Standard de facto classification

\begin{tabular}{lcccc}
\hline & pool & peg & nonpeg & Pool \\
\hline$\#$ observations & 499 & 399 & 85 & 484 \\
$\beta$ & $.42^{\text {aa }}$ & $.52^{\text {aa }}$ & .05 & .05 \\
$\beta$ std error & .03 & .04 & .09 & .10 \\
$\beta_{2}$ & & & & $.47^{\text {aa }}$ \\
$\beta_{2}$ std error & .26 & .41 & .00 & .09 \\
$R^{2}$ & & & & .33 \\
\hline
\end{tabular}

Bretton Woods

\begin{tabular}{lcccc}
\hline & pool & peg & nonpeg & pool \\
\hline \# observations & 227 & 208 & na & na \\
$\beta$ & $-.20^{\mathrm{b}}$ & $-.26^{\mathrm{a}}$ & & \\
$\beta$ std error & .11 & .11 & & \\
$\beta_{2}$ & & & & \\
$\beta_{2}$ std error & & & & \\
$R^{2}$ & .02 & .04 & & \\
\hline
\end{tabular}

\begin{tabular}{lcccc}
\multicolumn{4}{c}{ Post-Bretton Woods } \\
\hline & pool & peg & nonpeg & pool \\
\hline \# observations & 1920 & 748 & 1103 & 1848 \\
$\beta$ & $.36^{\text {aa }}$ & $.46^{\text {aa }}$ & $.27^{\text {aa }}$ & $.26^{\text {aa }}$ \\
$\beta$ std error & .05 & .04 & .08 & .08 \\
$\beta_{2}$ & & & & $.19^{\mathrm{a}}$ \\
$\beta_{2}$ std error & & & & .09 \\
$R^{2}$ & .03 & .19 & .01 & .03 \\
\hline
\end{tabular}

aa denotes a coefficient statistically significantly different from zero at the $99 \%$ level, a at $95 \%$, and b at $90 \%$.

${ }^{32} \mathrm{DW}$ statistics never indicate autocorrelation problems for the differences regressions. Due to the cross-sectional nature of the data, robust standard errors are reported. 


\section{Table 2. Annual differences on pooled sample}

Table $2 \mathrm{a}$

\begin{tabular}{lccccc}
\hline & pool & peg & nonpeg & $\begin{array}{c}\text { no capital } \\
\text { controls }\end{array}$ & $\begin{array}{c}\text { capital } \\
\text { controls }\end{array}$ \\
\hline \# observations & 2646 & 1355 & 1202 & 1076 & 1541 \\
$\beta$ & $.35^{\text {aa }}$ & $.43^{\text {aa }}$ & $.26^{\text {aa }}$ & $.56^{\text {aa }}$ & $.26^{\text {aa }}$ \\
$\beta$ std error & .04 & .03 & .08 & .05 & .06 \\
$R^{2}$ & .03 & .17 & .01 & .11 & .01 \\
\hline
\end{tabular}

Table $2 b$

\begin{tabular}{lcccc}
\hline & $\begin{array}{c}\text { peg \& no } \\
\text { capital controls }\end{array}$ & $\begin{array}{c}\text { peg with capital } \\
\text { controls }\end{array}$ & $\begin{array}{c}\text { nonpeg \& no } \\
\text { capital controls }\end{array}$ & $\begin{array}{c}\text { nonpeg with } \\
\text { capital controls }\end{array}$ \\
\hline \# observations & 613 & 739 & 423 & 753 \\
$\beta$ & $.61^{\text {aa }}$ & $.36^{\text {aa }}$ & $.53^{\text {aa }}$ & .15 \\
$\beta$ std error & .05 & .04 & .07 & .11 \\
$R^{2}$ & .30 & .13 & .06 & .00 \\
\hline
\end{tabular}

Table 2c

\begin{tabular}{lcccc}
\hline & pool & pool & $\begin{array}{c}\text { pool - no } \\
\text { constant } R\end{array}$ & $\begin{array}{c}\text { pool - no } \\
\text { constant } R\end{array}$ \\
\hline \# observations & 2526 & 2526 & 2305 & 2305 \\
$\beta$ & $.17^{\mathrm{b}}$ & .15 & $.19^{\mathrm{b}}$ & .16 \\
$\beta$ std error & .10 & .11 & .10 & .12 \\
$\beta_{2}$ & $.17^{\mathrm{b}}$ & $.21^{\mathrm{b}}$ & $.24^{\mathrm{aa}}$ & $.31^{\mathrm{a}}$ \\
$\beta_{2}$ std error & .09 & .12 & .09 & .12 \\
$\beta_{3}$ & $.33^{\text {aa }}$ & $.39^{\mathrm{aa}}$ & $.31^{\mathrm{aa}}$ & $.40^{\mathrm{aa}}$ \\
$\beta_{3}$ std error & .08 & .14 & .09 & .14 \\
$\beta_{4}$ & & -.17 & & -.22 \\
$\beta_{4}$ std error & .15 & & .16 \\
$R^{2}$ & .03 & .03 & .03 & .03 \\
\hline
\end{tabular}

$\beta=$ coefficient on $\Delta R_{b}$

$\beta_{2}=$ coefficient on (peg) $\times \Delta R_{b}$

$\beta_{3}=$ coefficient on (no capital controls) $\times \Delta R_{b}$

$\beta_{4}=$ coefficient on (peg) $\times($ no capital controls $) \times \Delta R_{b}$

aa denotes a coefficient statistically significantly different from zero at the $99 \%$ level, a at $95 \%$, and b at $90 \%$.

"No constant $R$ " signals that interest rates which are constant over long periods of the sample have been removed. 


\section{Table 3. PSS results}

Gold Standard de jure

\begin{tabular}{lcccccccc}
\hline & \# obs & $\theta$ & $\gamma$ & tstat $\theta$ & sig at 0 & sig at 1 & half-life & EC $\theta$ \\
\hline Pegs & & & & & & & & \\
France & 520 & -0.19 & 0.56 & -7.37 & 1 & 1 & 3.30 & -0.07 \\
Germany & 499 & -0.20 & 0.59 & -4.20 & 1 & 1 & 3.14 & -0.19 \\
Netherlands & 457 & -0.18 & 0.63 & -7.26 & 1 & 1 & 3.46 & -0.13 \\
Belgium & 529 & -0.22 & 0.60 & -7.33 & 1 & 1 & 2.80 & -0.14 \\
Italy & 107 & -0.23 & 0.47 & -3.48 & 1 & 1 & 2.69 & -0.17 \\
Austria & 251 & -0.10 & 0.27 & -2.76 & 0 & 0 & 6.82 & -0.04 \\
Portugal & 77 & -0.08 & 1.03 & -1.68 & 0 & 0 & 8.00 & -0.10 \\
Denmark & 361 & -0.09 & 0.57 & -4.09 & 1 & 1 & 7.14 & -0.08 \\
US & 401 & -0.66 & 0.41 & -10.00 & 1 & 1 & 0.64 & -0.35 \\
India & 198 & -0.28 & -0.13 & -3.72 & 1 & 1 & 2.08 & -0.21 \\
Switzerland & 258 & -0.22 & 0.43 & -5.33 & 1 & 1 & 2.79 & -0.04 \\
Sweden & 258 & -0.14 & 0.39 & -3.87 & 1 & 1 & 4.73 & -0.07 \\
Norway & 245 & -0.11 & 0.54 & -4.41 & 1 & 1 & 5.82 & -0.05 \\
\hline Nonpegs & & & & & & & & \\
Netherlands & 60 & -0.34 & 0.96 & -4.19 & 1 & 1 & 1.67 & -0.37 \\
Italy & 256 & -0.21 & 0.49 & -6.16 & 1 & 1 & 2.89 & -0.11 \\
Austria & 264 & -0.19 & 0.50 & -5.41 & 1 & 1 & 3.35 & -0.10 \\
Spain & 386 & -0.09 & 0.06 & -3.94 & 1 & 1 & 7.76 & -0.02 \\
Portugal & 276 & -0.05 & -0.10 & -2.03 & 0 & 0 & 13.41 & -0.01 \\
Russia & 309 & -0.19 & -0.06 & -6.14 & 1 & 1 & 3.36 & 0.00 \\
India & 163 & -0.23 & 0.94 & -5.12 & 1 & 1 & 2.60 & -0.18 \\
\hline Nonpegs & & -0.19 & 0.40 & -4.71 & $86 \%$ & $86 \%$ & 5.00 & -0.11 \\
Pegs & & -0.21 & 0.49 & -5.04 & $85 \%$ & $85 \%$ & 4.11 & -0.13 \\
\hline & & & & & & & &
\end{tabular}

$\theta$

$\gamma$

t-stat $\theta$

sig at 0

sig at 1

half-life

the adjustment speed to shocks in the levels relationship

the levels relationship

the t-stat on the adjustment speed which is used to determine the significance of the levels relationship.

signifies whether we can reject no levels relationship if we assume the data is stationary signifies whether we can reject no levels relationship if we assume the data is non-stationary the half-life of a shock (in months) based on the adjustment speed

EC $\theta$

the adjustment speed when one runs the data in error-correction form assuming a level relationship equal to 1 , using six lags of change in base rate and change in local rate. 


\section{Table 3. PSS results (cont.)}

Gold Standard de facto

\begin{tabular}{lcccccccc}
\hline & \# obs & $\theta$ & $\gamma$ & tstat $\theta$ & sig at 0 & sig at 1 & half-life & EC $\theta$ \\
\hline Pegs & & & & & & & & \\
France & 507 & -0.13 & 0.45 & -4.45 & 1 & 1 & 4.90 & -0.07 \\
Germany & 504 & -0.20 & 0.59 & -4.22 & 1 & 1 & 3.12 & -0.19 \\
Netherlands & 529 & -0.21 & 0.69 & -8.85 & 1 & 1 & 2.98 & -0.16 \\
Belgium & 499 & -0.17 & 0.65 & -5.18 & 1 & 1 & 3.64 & -0.13 \\
Italy early peg & 95 & -0.29 & 0.44 & -4.16 & 1 & 1 & 2.04 & -0.06 \\
Italy late peg & 141 & -0.19 & 0.38 & -3.41 & 1 & 1 & 3.31 & -0.14 \\
Austria early peg & 111 & -0.70 & 0.27 & -4.85 & 1 & 1 & 0.57 & -0.13 \\
Austria late peg & 242 & -0.09 & 0.28 & -2.59 & 0 & 0 & 7.35 & -0.04 \\
Spain early peg & 93 & -0.02 & 1.46 & -0.95 & 0 & 0 & 28.96 & -0.04 \\
Spain late peg & 48 & -0.32 & 0.31 & -3.01 & 1 & 0 & 1.79 & -0.06 \\
Portugal early & 60 & -0.06 & 1.14 & -1.01 & 0 & 0 & 11.61 & -0.10 \\
Portugal late peg & 48 & -0.64 & 0.01 & -24.54 & 1 & 1 & 0.69 & 0.00 \\
Russia & 72 & -0.26 & 0.29 & -3.26 & 1 & 1 & 2.32 & -0.05 \\
Denmark & 361 & -0.09 & 0.57 & -4.09 & 1 & 1 & 7.14 & -0.08 \\
US & 377 & -0.66 & 0.42 & -9.64 & 1 & 1 & 0.64 & -0.35 \\
India early peg & 60 & -0.32 & -1.15 & -2.43 & 0 & 0 & 1.83 & -0.11 \\
India late peg & 122 & -0.49 & 0.25 & -3.09 & 1 & 0 & 1.04 & -0.39 \\
Switzerland & 258 & -0.22 & 0.43 & -5.33 & 1 & 1 & 2.79 & -0.04 \\
Sweden & 258 & -0.14 & 0.39 & -3.87 & 1 & 1 & 4.73 & -0.07 \\
Norway & 245 & -0.11 & 0.54 & -4.41 & 1 & 1 & 5.82 & -0.05 \\
\hline Nonpegs & & & & & & & & \\
Spain & 112 & -0.10 & -0.14 & -2.39 & 0 & 0 & 6.78 & -0.02 \\
Portugal & 112 & -0.15 & -0.08 & -2.53 & 0 & 0 & 4.31 & -0.01 \\
Russia 1 & 59 & -.18 & -0.09 & -2.04 & 0 & 0 & 3.39 & .02 \\
Russia 2 & 71 & -.13 & -0.41 & -2.12 & 0 & 0 & 4.97 & -.03 \\
India & 145 & -0.22 & -0.16 & -3.34 & 1 & 1 & 2.75 & -0.18 \\
\hline Nonpegs & & -0.16 & -0.18 & -2.44 & $20 \%$ & $20 \%$ & 4.44 & -0.04 \\
Pegs & & -0.27 & 0.43 & -5.25 & $80 \%$ & $70 \%$ & 4.79 & -0.12 \\
\hline
\end{tabular}


Table 3. PSS results (cont.)

\begin{tabular}{|c|c|c|c|c|c|c|c|c|}
\hline \multicolumn{9}{|c|}{ Bretton Woods } \\
\hline Pegs & \#obs & $\theta$ & $\gamma$ & tstat $\theta$ & sig at 0 & sig at 1 & half-life & $\mathrm{EC} \theta$ \\
\hline Australia full & 144 & -0.07 & 0.53 & -3.77 & 1 & 1 & 9.15 & -0.05 \\
\hline Austria full & 130 & -0.03 & 0.65 & -1.25 & 0 & 0 & 21.42 & -0.03 \\
\hline Barbados full 1966:12 ff & 48 & -0.12 & 0.60 & -2.25 & 0 & 0 & 5.24 & -0.04 \\
\hline Belgium full & 144 & -0.12 & 0.56 & -3.18 & 1 & 0 & 5.30 & -0.05 \\
\hline Canada $1963: 1$ to $1970: 5$ & 89 & -0.14 & 0.90 & -2.60 & 0 & 0 & 4.65 & -0.13 \\
\hline France 1960:1 ff & 131 & -0.04 & 1.70 & -2.11 & 0 & 0 & 15.96 & -0.03 \\
\hline Germany $1959: 1$ to $1969: 8$ & 115 & -0.21 & 0.56 & -3.78 & 1 & 1 & 2.90 & -0.05 \\
\hline India full & 144 & -0.40 & 0.17 & -6.06 & 1 & 1 & 1.35 & -0.11 \\
\hline Italy full & 144 & -0.06 & 0.85 & -2.60 & 0 & 0 & 10.34 & -0.05 \\
\hline Jamaica full & 144 & -0.06 & -0.05 & -2.30 & 0 & 0 & 12.25 & -0.01 \\
\hline Japan full & 144 & -0.13 & -0.29 & -2.42 & 0 & 0 & 4.96 & -0.04 \\
\hline Malaysia 1961:12 ff & 118 & -0.08 & 0.03 & -2.14 & 0 & 0 & 8.53 & -0.02 \\
\hline Netherlands full & 144 & -0.08 & 1.20 & -2.83 & 0 & 0 & 8.84 & -0.09 \\
\hline Southafrica full & 144 & -0.03 & 0.46 & -2.24 & 0 & 0 & 25.47 & -0.02 \\
\hline Sweden full & 144 & -0.12 & 1.05 & -3.18 & 1 & 0 & 5.48 & -0.13 \\
\hline Switzerland full & 144 & -0.05 & 0.68 & -3.31 & 1 & 1 & 12.73 & -0.02 \\
\hline Pakistan 1964:1 ff & 83 & -0.05 & -0.11 & -1.62 & 0 & 0 & 12.5 & -0.02 \\
\hline Trinidadandtobago 1964:12ff & 72 & -0.13 & 0.13 & -2.16 & 0 & 0 & 5.15 & -0.01 \\
\hline Unitedkingdom 59:1 to $67: 10$ & 106 & -0.10 & 0.70 & -2.66 & 0 & 0 & 6.72 & -0.12 \\
\hline Zimbabwe 1962:2 ff & 106 & -0.10 & -0.06 & -2.89 & 1 & 0 & 6.67 & 0.00 \\
\hline \multicolumn{9}{|l|}{ Nonpegs } \\
\hline Brazil full (64:1 to $70: 12)$ & 83 & -0.04 & 0.07 & -1.32 & 0 & 0 & 17.72 & -0.05 \\
\hline Brazil $68: 1$ to $70: 12$ & 36 & -0.23 & -0.51 & -3.14 & 1 & 0 & 2.71 & 0.05 \\
\hline Pegs & 122 & -0.11 & 0.51 & -2.77 & $35 \%$ & 0.20 & 9.28 & -0.05 \\
\hline Nonpegs & 36 & -0.23 & -0.51 & -3.14 & 1.00 & 0.00 & 2.71 & 0.05 \\
\hline
\end{tabular}

Post-Bretton Woods Averages

\begin{tabular}{lccccccc}
\hline & $\theta$ & $\gamma$ & tstat $\theta$ & sig at 0 & sig at 1 & half-life & EC $\theta$ \\
\hline Nonpegs & -0.06 & -0.43 & -2.21 & $31 \%$ & $25 \%$ & 35.16 & -0.04 \\
Occasional pegs & -0.11 & 0.68 & -2.38 & $24 \%$ & $20 \%$ & 10.56 & -0.08 \\
Pegs & -0.19 & 0.93 & -2.56 & $43 \%$ & $27 \%$ & 7.84 & -0.11 \\
\hline
\end{tabular}


Figure 1a. Base in Gold Standard era

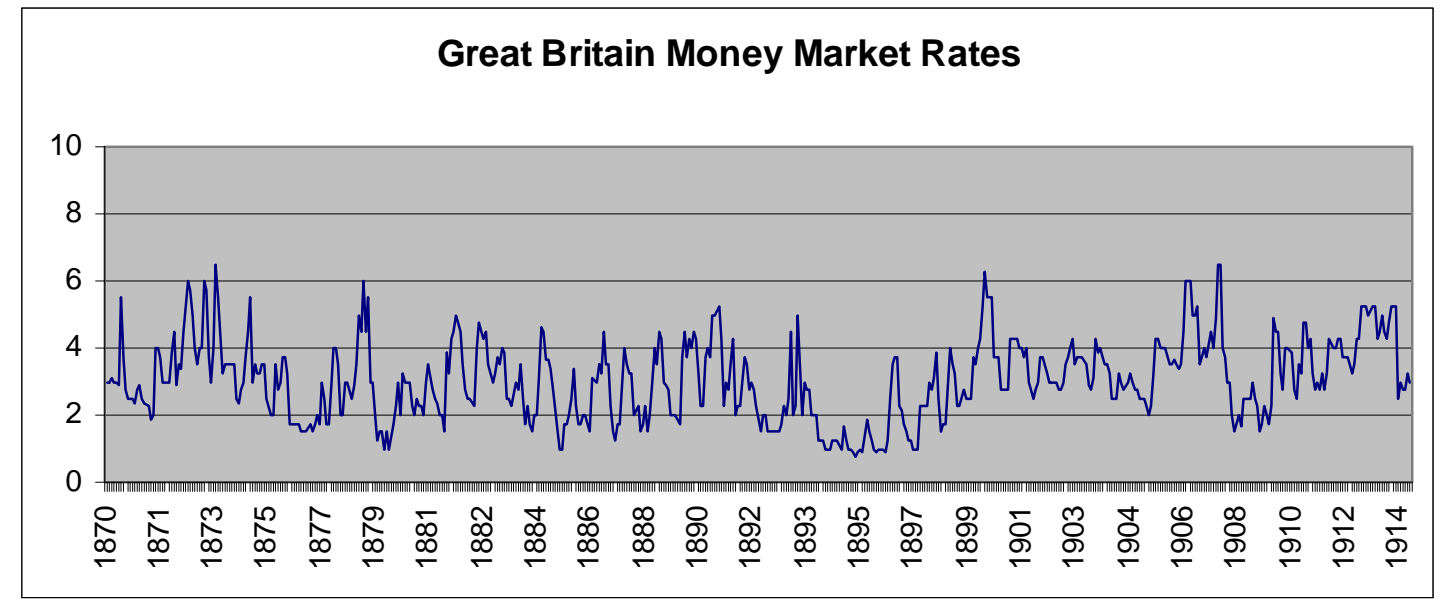

Figure 1b. Base in Bretton Woods era

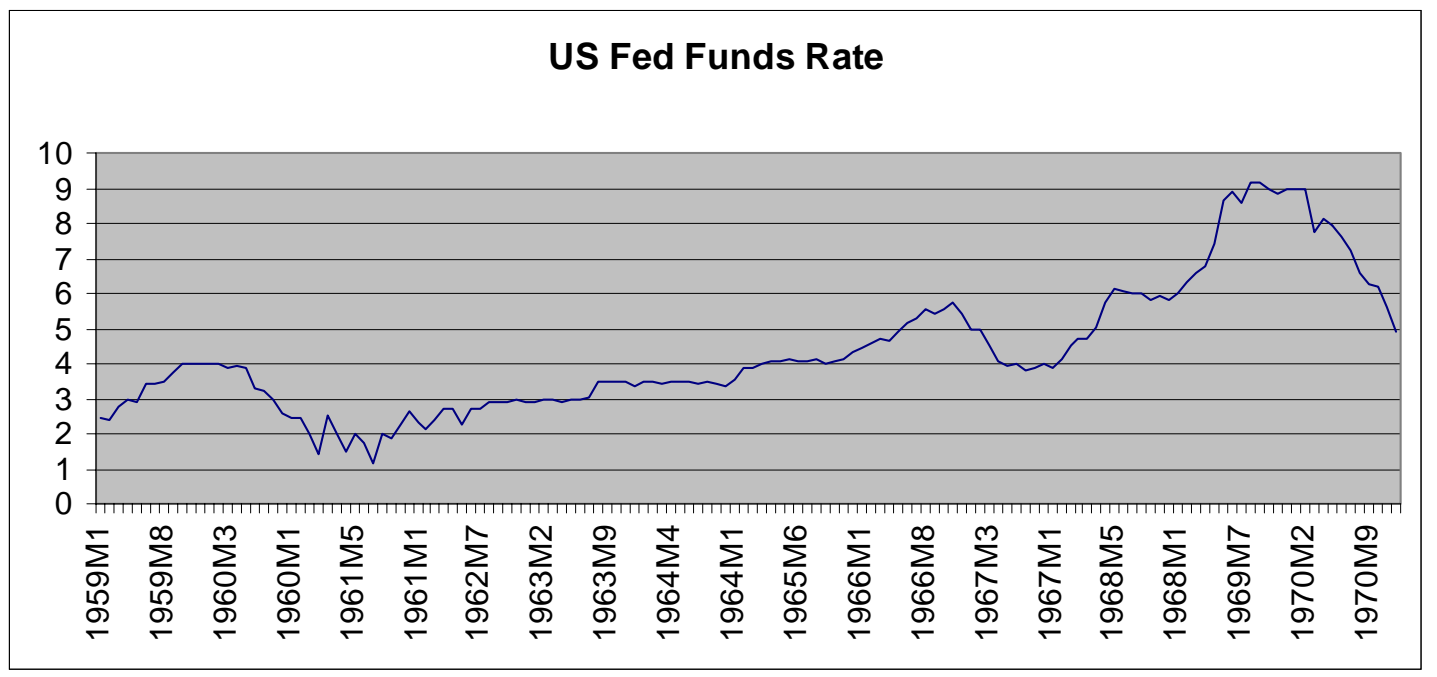

Figure 1c. Base in Post-Bretton Woods era (not all countries are based to US, but it is an example)

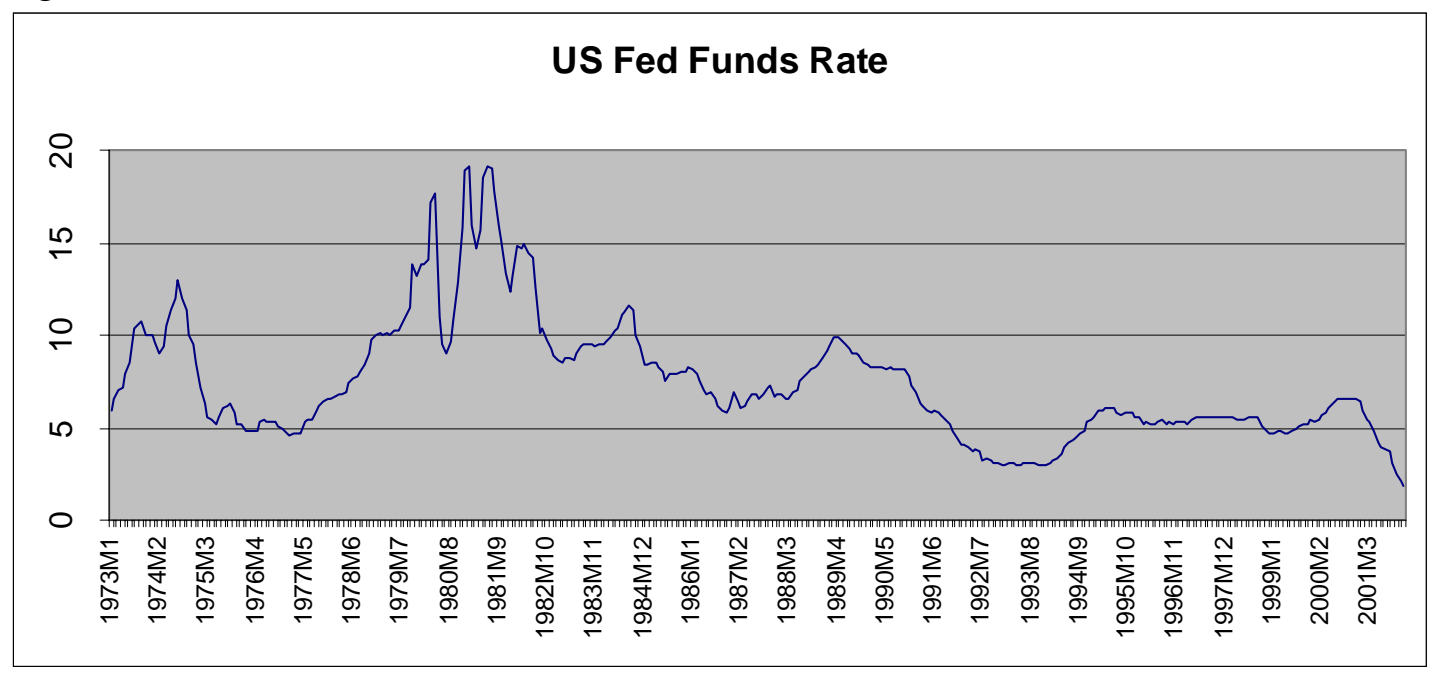

